\title{
Transport Direction and Scandinavian Source Regions of the Saalian Glacial and Glaciofluvial Deposits in a Case Study of Łubienica-Superunki (Central Poland)
}

\author{
Maria Górska-Zabielska ${ }^{1, * \mathbb{D}}$, Ewa Smolska ${ }^{2}$ (D) and Lucyna Wachecka-Kotkowska ${ }^{3}$ (D) \\ 1 Institute of Geography and Environmental Sciences, Jan Kochanowski University, 25-406 Kielce, Poland \\ 2 Department of Physical Geography, University of Warsaw, 00-927 Warszawa, Poland; e.smolska@uw.edu.pl \\ 3 Department of Geology and Geomorphology, University of Łódź, 90-139 Łódź, Poland; \\ lucyna.wachecka@geo.uni.lodz.pl \\ * Correspondence: maria.gorska-zabielska@ujk.edu.pl
}

check for

updates

Citation: Górska-Zabielska, M.; Smolska, E.; Wachecka-Kotkowska, L. Transport Direction and Scandinavian Source Regions of the Saalian Glacial and Glaciofluvial Deposits in a Case Study of Łubienica-Superunki (Central Poland). Minerals 2021, 11, 762. https://doi.org/10.3390/ $\min 11070762$

Academic Editor: Frederick Lin Sutherland

Received: 22 June 2021

Accepted: 12 July 2021

Published: 14 July 2021

Publisher's Note: MDPI stays neutral with regard to jurisdictional claims in published maps and institutional affiliations.

Copyright: (c) 2021 by the authors. Licensee MDPI, Basel, Switzerland. This article is an open access article distributed under the terms and conditions of the Creative Commons Attribution (CC BY) license (https:// creativecommons.org/licenses/by/ $4.0 /)$.

\begin{abstract}
The article contains detailed petrographic studies, which covered a coarse and mediumgrain gravel fraction of two layers of glacial till (units ŁS II and ŁS IV) and two layers of sandgravelly outwash deposits (units ŁS I and ŁS III) related to the Odranian Glaciation (MIS6, Saalian) in Łubienica-Superunki, North Mazovian Lowland, central Poland. Additionally, the indicator erratics were identified to indicate their Scandinavian source areas and the directions of the ice sheet transgressions. This case study is discussed against the background of similar sediments and forms from the same age but from other places in the Polish Lowlands. Regardless of the facies types and fractions, crystalline rocks dominated over all other petrographic groups in all samples. The most common were the indicator erratics derived from the Aland Islands, followed by those from the south-eastern area of Sweden (Småland) and from Dalarna in central Sweden. Amongst the erratics of limited indicative significance, the most common were Lower Palaeozoic limestones and the Jotnian red sandstones. The complex petrographic analyses point to the dipartite nature of the studied profile. This separateness was confirmed by the TBC: $59.1-59.2^{\circ} \mathrm{N}$ and $18.0-18.2^{\circ} \mathrm{E}$ for the lower units and $58.8-59.4^{\circ} \mathrm{N}$ and $17.3-17.9^{\circ} \mathrm{E}$ for the upper ones.
\end{abstract}

Keywords: petrographic analysis; Fennoscandian erratics; Scandinavian provenance; MIS6; NorthMazovian Lowland; Central Europe

\section{Introduction}

Indicator erratics, along with auxiliary erratics, have been one of the main sources of evidence of the Pleistocene ice-sheet advances [1-7]. Research has been conducted to understand the source areas of coarse-gravel erratics deposited along with glacial till. Based on their qualitative and quantitative characteristics, the theoretical boulder centre (TBC) [5] can be determined. This enables a highly reliable reconstruction of ice-sheet exaration areas, as well as of the directions and paths of advancing ice masses [8-24]. In Europe, both the last and earlier Pleistocene glaciations have been studied in this regard [10,16,25-31]. Indicator and auxiliary erratics found in Poland have also been described, and their source areas have been identified [29,32-38]. Recently, research has focused on the Middle Polish Glaciation-Odranian/Wartanian (Saalian, Marine Oxygen-Isotope Stage (MIS) 6) [33,39-44].

It is believed that ice streams [45-48] are responsible for the long-distance transport of rocks from their source areas to deposition sites, where they accumulate in the form of Boothia scattering cones [14,45]. Hence, it is important to understand the set of indicator erratics in both ice-marginal zones and their hinterland areas. The results of such regional studies are sometimes used to determine the stratigraphic position of tills and to better/more accurately identify the movement directions of main glacial streams [33,39,42,49-52]. Such studies are not common. 
In some places/regions, glacial till beds are thin, either because of limited deposition or their subsequent reduction; thus, they often contain small amounts of gravel. On the other hand, if glaciofluvial deposits contain a large amount of fractions appropriate for the analysis of erratics and their chronostratigraphic position is known, they can be used as an auxiliary to determine the likely paths of ice-sheet advance [53]. The usefulness of glaciofluvial deposits has been discussed because transport in aquatic environment is selective with respect to the size and resistance to abrasion [52-56]. Glaciofluvial deposits may be depleted primarily in limestones $[33,42,57,58]$. Comparative studies of glacial tills and glaciofluvial deposits of the same age are scarce [35,55,59-61]. As a consequence, petrographic research of gravels, as part of the detailed geological map of Poland $(1: 50,000)$, has been carried out according to strict rules and only with regard to till. In Poland, there are very few, scattered petrographic studies of glaciofluvial sediments, which does not allow detailed comparative analyses to be undertaken. The results of petrographic research have been treated as unreliable in advance and they have not been included in palaeogeographic and lithostratigraphic interpretations. In contrast, in Germany [16,62,63], the study of petrographic composition has not been limited only to till, but also carried out in glaciofluvial sediments. Studies on the petrographic composition of glaciofluvial sediments that were carried out even earlier can be found in the literature, e.g., in Lithuania or Latvia [64-67]. The usefulness of glaciofluvial sediments was not categorically rejected by Saarnisto [68].

In light of the issues outlined above, the aim of this research was to analyse the petrographic spectrum of gravelly sediments of the Middle Polish Glaciation from the Łubienica-Superunki site in the North Mazovian Lowland (central Poland) (Figure 1A) and to identify the Scandinavian source areas of erratics. Studies of lithology and petrography of the deposits at the Łubienica-Superunki site enable palaeogeographic reconstruction of the penultimate glaciation (Central Poland complex, MIS6, Saalian) in central Poland. In the article, we also tried to provide a very preliminary chronostratigraphic assignment of the studied sediments. We realise that more research is needed to address this thread.

This case study is discussed against the background of similar sediments and forms from the same age, but located in the neighbouring areas and in the marginal part of the Wartanian maximum ice-sheet, on the border of the Polish Lowlands and Uplands, approximately $200 \mathrm{~km}$ south. Such a comparison allows for a broad comparison of the state of the environment and the origin of the glaciofluvial and glacial material in different parts of the same ice cover, but in different parts of the Polish Lowlands.

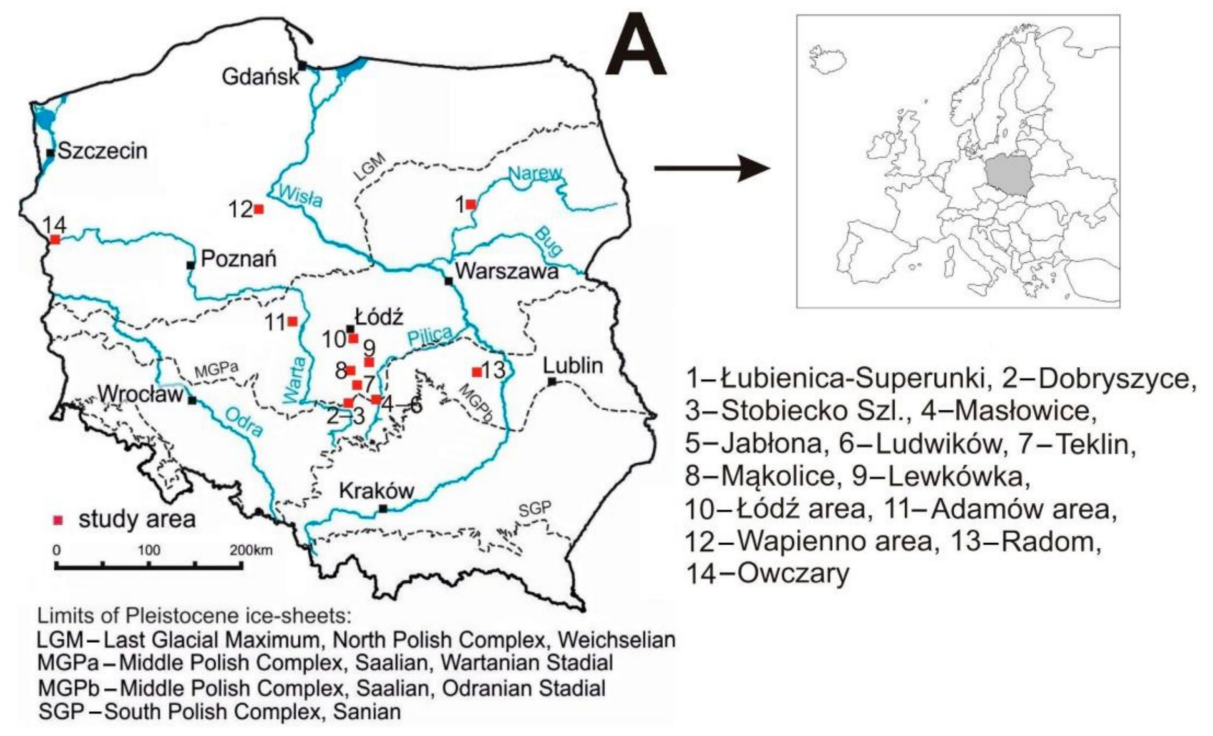

Figure 1. Cont. 


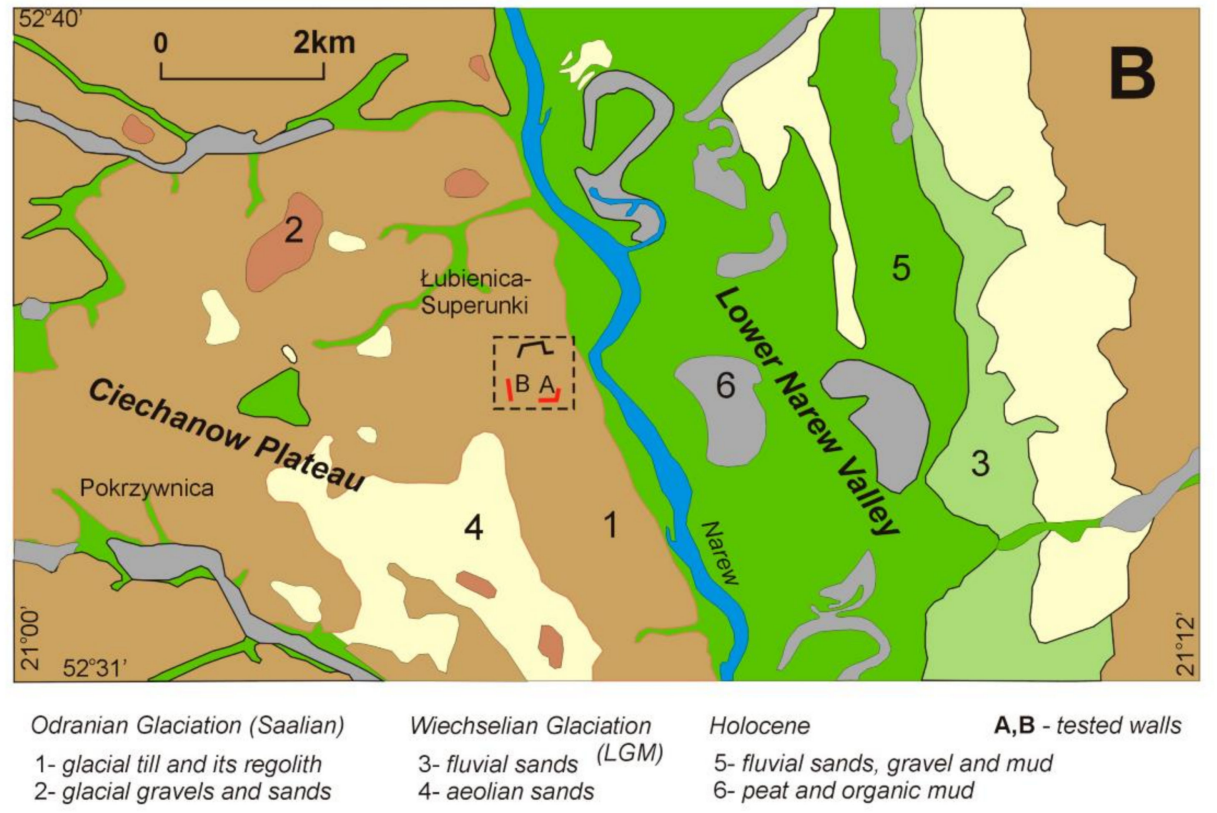

Figure 1. (A) Limits of Pleistocene ice-sheets (upon $[69,70]$ ) study site (1) and other research sites cited in the discussion: 2-9-[40]; 10-[32,33], 11-[39], 12-[71,72], 13-[42], 14-[41]. (B) The location of the tested walls ( $A$ and $B$, in red) in the gravel pit in Łubienica-Superunki against the surface deposits within a fragment of the Detailed Geological Map of Poland (DGMP), 1:50,000 scale, Serock sheet (No. 450). Source: Polish Geological Institute, Institute-National Research Institute, Warsaw, https:/ / geolog.pgi.gov.pl (accessed on: 18 December 2020). The location of the area against the background of the ice-sheet limit of the Wartanian Glaciation and its previously distinguished stadials is shown in (A).

Due to the presence of tills and glaciofluvial deposits at the Łubienica-Superunki site the authors conducted detailed petrographic studies of both these lithological types. The usefulness of glaciofluvial deposits in the interpretation of ice-sheet provenance is emphasised as an accompanying goal of this study.

\section{Study Area}

The Łubienica-Superunki site is located in central Poland, in the North Mazovian Lowland, north of Warsaw and south of Pułtusk (52 $37^{\prime} 52^{\prime \prime}$ N; $21^{\circ} 5^{\prime} 34^{\prime \prime}$ E; Figure 1A). The gravel pit is located in a flat glacial plateau (Ciechanów Upland) on the boundary with the lower Narew River valley (Figure 1B). The elevations of the glacial plateau vary between 89 and $104 \mathrm{~m}$ a.s.l. It is enriched with latitudinal river valleys running towards the Narew valley.

The Łubienica-Superunki gravel pit exposes thick (up to $15 \mathrm{~m}$ ) glaciofluvial sands and sandy gravels, and thin (up to $1 \mathrm{~m}$ ) glacial tills (Figure 2). The features of the glaciofluvial sediments are discussed in the papers by Giriat et al. [73] and Smolska et al. [74]. The study covered two (A and B in Figure 1B) pit walls of the Eubienica-Superunki gravel pit in its southern part. 


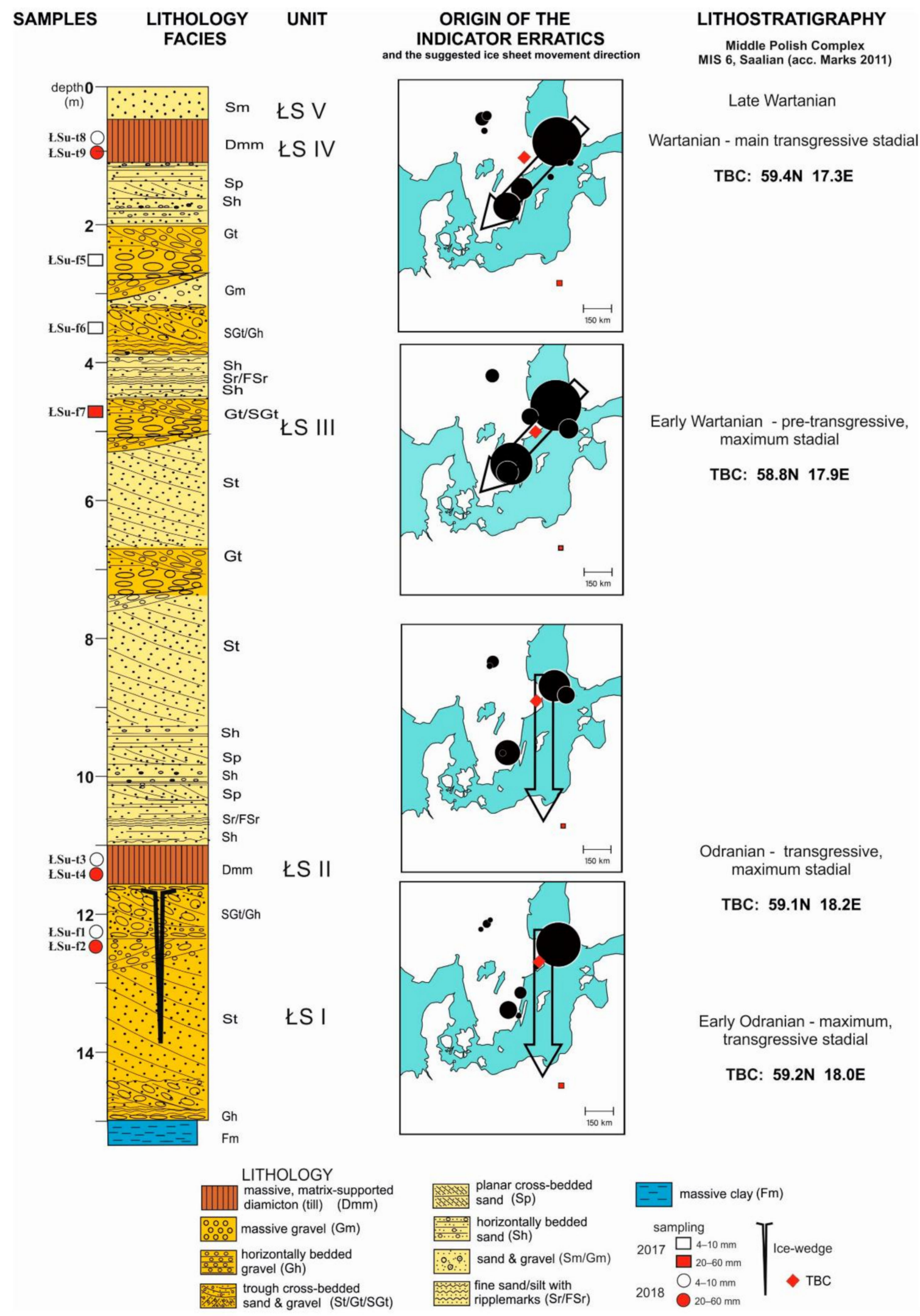

Figure 2. Schematic depth profile of deposits in Łubienica-Superunki with marked sampling sites, origin of indicator erratics and lithostratigraphy according to Marks [69]. 
At the bottom of the gravel pit, the lower glaciofluvial series (unit ŁS I; Figure 3; Table 1) is exposed [73]. It is sandy gravel, with a higher proportion of gravel and weaker sorting towards the layer top. In its layer top, Dabski et al. [75] report the presence of a large composite ice-wedge pseudomorph, originally filled with ice and sand. According to those authors, such a location of the wedge indicates long-term permafrost in the icemarginal zone of advancing ice sheet, as interpreted by Frankiewicz [76], and a long break in glaciofluvial deposition at this location. Above, there is a discontinuous layer of lower glacial till (ŁS II; Figure 3; Table 1), probably of the Odranian age [77] or deposited during the older stadial of the Wartanian glaciation [76,78]. The till layer (locally reduced) has a small thickness of approximately $0.5-1 \mathrm{~m}$. During the studies, it was best seen in the central part of the gravel pit (Figure 3).

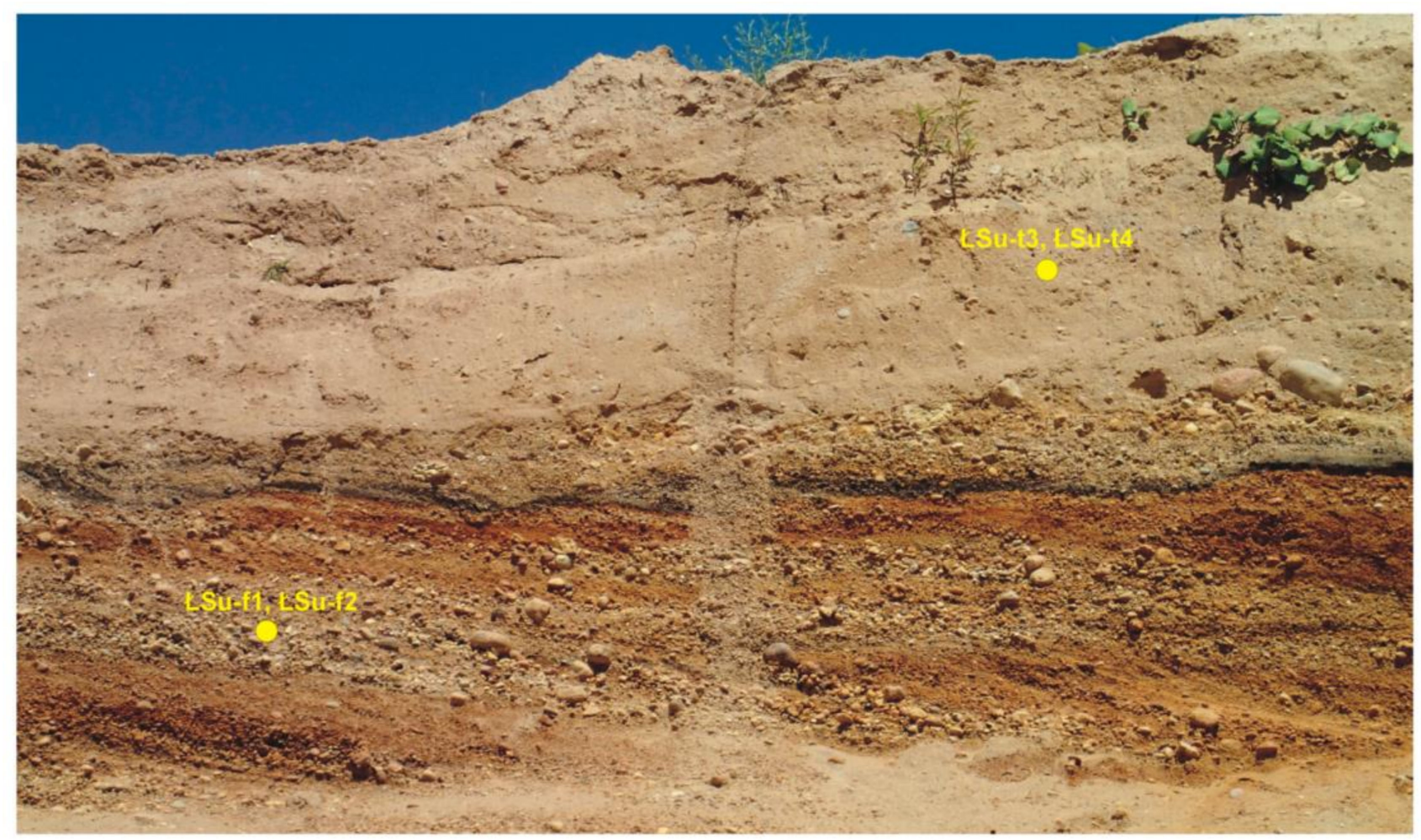

Figure 3. General view of pit wall B with unit ŁS I and ŁS II at the top; sampling sites, as well as the ice-wedge pseudomorph are shown.

Above this, there is the upper glaciofluvial series (unit ŁS III; Figures 2 and 4A; Table 1). Its sandy and gravelly sediments are clearly visible in wall A of the gravel pit (Figures $1 \mathrm{~B}$ and $4 \mathrm{~A}$ ). The thickness of the glaciofluvial sediments is about $10 \mathrm{~m}$. It is covered by a discontinuous layer of upper sandy till (unit ŁS IV; Figures 2 and 4B; Table 1), which was assigned by Nowak [79] to the Wierzbica Phase of the North Mazovian Stadial (formerly the middle Wartanian glaciation). The research by Frankiewicz [76] showed that the elongated, high hills in the neighbourhood (central and southern part of the Serock sheet, Detailed Geological Map of Poland, 1:50,000, sheet No. 450), considered by Nowak $[79,80]$ as the frontal moraines of this phase, turned out to be either crevasse-fill landforms or dead-ice moraines. The profile is closed in the layer top by sedimentary covers, connected by Kucharska and Pochocka-Szwarc [78] and Frankiewicz [76] with the recession of the middle stage of the Wartanian glaciation. 

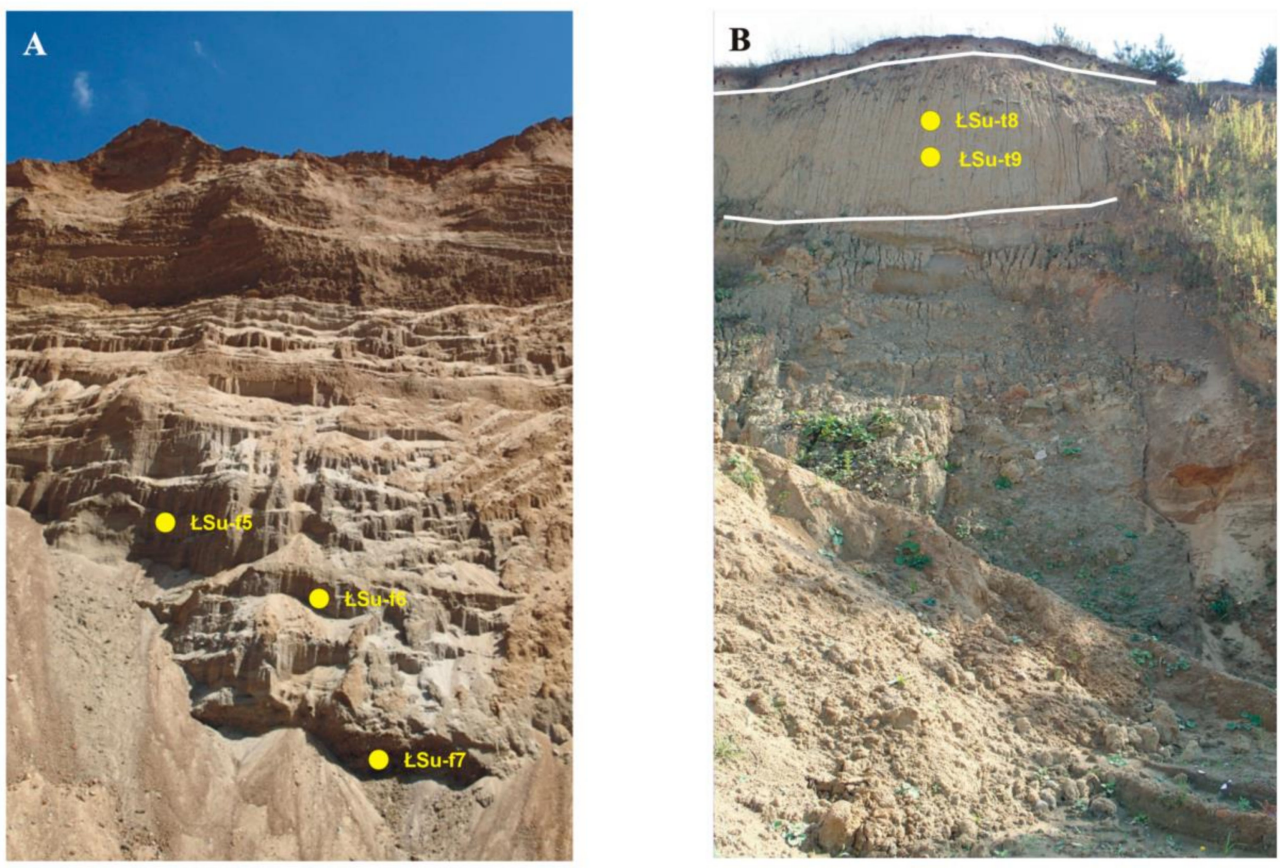

Figure 4. (A) Upper layers of outwash sediments (unit SŁ III) in a horizontal part of wall A; (B) Closeup of the upper till (unit SŁ IV) in a vertical part of wall A of the gravel pit.

\section{Materials and Methods}

For the lithological characterisation of sediments from the Łubienica-Superunki gravel pit, two mining pit walls (Figure 1B) were selected, providing a combined, almost complete vertical lithological section (Figure 2). The lithofacies code by Miall [81], modified by Zieliński [82], and by Zieliński and Pisarska-Jamroży [83] was used to describe the sediments.

Two till layers (unit ŁS II and unit ŁS IV) and two glaciofluvial layers (unit ŁS I and ŁS III; Table 1; Figures 2-4) were sampled in 2017 [49] and 2018, according to the method of sampling coarse gravel $(20-60 \mathrm{~mm})$ in $[5,10,84]$ and medium gravel $(4-10 \mathrm{~mm})$ deposits for petrographic analyses in [85-90].

The petrographic composition of coarse and medium gravel samples was analysed. The following petrographic types have been identified in the investigated deposits: $\mathrm{Cr}-$ crystallines, LP1—Lower Palaeozoic limestones (grey), CL-Cretaceous limestones, Ssandstones, F-flints and Q-quartz. The presence of Fennoscandian indicator erratics was examined only in coarse gravel samples. The initial petrographic analysis of gravel in the field and detailed analysis in the laboratory were carried out in accordance with the methodological principles provided by many authors and presented in, e.g., Górska [55,59] and Górska-Zabielska [29].

In the course of the field and laboratory work, the following quantities of rock fragments were covered by the petrographic analysis of coarse gravel fraction:

- From the lower glaciofluvial layer ŁS I (sample ŁSu-f2) - 392,

- From the lower till ŁS II (sample ŁSu-t4)—368,

- From the upper glaciofluvial layer ŁS III (sample ŁSu-f7)—521,

- From the upper till ŁS IV (sample ŁSu-t9)—301.

The analysis of indicator erratics covered 9.9\% (ŁSu-f2), 11.9\% (ŁSu-t4), 10.1\% (ŁSu-f7) and $18.6 \%$ (ESu-t9) of the above-mentioned coarse gravel rocks. According to Meyer's suggestions $[10,80]$, these amounts are sufficient to indicate the sources of sediments transported by ice sheet to the Mazovia Region, central Poland.

Medium gravel material was analysed in 2017 (samples ŁSu-f5 and ŁSu-f6 from unit ŁS III) and 2018 (sample ŁSu-f1 from unit ŁS I, and samples ŁSu-t3 and ŁSu-t8 from units ŁS II and ŁS IV, respectively; Table 1). The quartering method was used [89,90] to 
petrographically analyse a total of about 300 grains of the $4-10 \mathrm{~mm}$ fraction. All of these five samples will be discussed in this paper.

Table 1. Lithostratigraphical situation of the sediments in the Łubienica-Superunki gravel pit (2018) and the types of samples taken for petrographic analyses.

\begin{tabular}{|c|c|c|c|c|c|}
\hline \multirow[b]{2}{*}{ Unit } & \multirow[b]{2}{*}{ Lithology } & \multicolumn{3}{|c|}{ Age Correlation of MIS (Marine Isotope Stage) 6 Deposits } & \multirow[b]{2}{*}{$\begin{array}{l}\text { Samples: Year of } \\
\text { Sampling, No, } \\
\text { Grain Size (mm) }\end{array}$} \\
\hline & & $\begin{array}{c}\text { Equivalents in } \\
\text { Western Europe [91] }\end{array}$ & $\begin{array}{c}\text { After Kucharska, } \\
\text { Pochocka-Szwarc [78], } \\
\text { Frankiewicz [76] }\end{array}$ & $\begin{array}{c}\text { Author's Proposal Based on } \\
\text { Wachecka-Kotkowska [70] } \\
\text { and Litho-Petrographic } \\
\text { Studies }\end{array}$ & \\
\hline ŁS V & Sandy cover deposits & & $\begin{array}{c}\text { Recession of the Middle } \\
\text { Stadial of the Wartanian } \\
\text { Glaciation }\end{array}$ & Late Wartanian stadial & - \\
\hline ŁS IV & Upper till (sandy) & & $\begin{array}{l}\text { Middle Stadial of the } \\
\text { Wartanian Glaciation }\end{array}$ & $\begin{array}{l}\text { Wartanian, main, } \\
\text { transgressive stadial }\end{array}$ & $\begin{array}{l}2018 \text { ŁSu-t8 (4-10) } \\
\text { ŁSu-t9 (20-60) }\end{array}$ \\
\hline ŁS III & $\begin{array}{l}\text { Upper glaciofluvial } \\
\text { layer }\end{array}$ & $\begin{array}{l}\text { Warthe } \\
\text { Drenthe }\end{array}$ & $\begin{array}{l}\text { Ice-sheet advance, } \\
\text { Middle Stadial of the } \\
\text { Wartanian Glaciation, } \\
\text { transgressive deposits } \\
\text { preceding till deposition }\end{array}$ & $\begin{array}{l}\text { Early Wartanian, } \\
\text { pre-transgressive, maximum } \\
\text { stadial }\end{array}$ & $\begin{array}{c}2017 \text { ŁSu-f5, ŁSu-f6 } \\
\text { ŁS2 (4-10) ŁSu-f7 } \\
\text { (20-60) }\end{array}$ \\
\hline ŁS II & $\begin{array}{l}\text { Discontinuous lower } \\
\text { till }\end{array}$ & & $\begin{array}{l}\text { Older Stadial of the } \\
\text { Wartanian Glaciation }\end{array}$ & $\begin{array}{l}\text { Odranian, maximum, } \\
\text { transgressive stadial }\end{array}$ & $\begin{array}{l}2018 \text { ŁSu-t3 (4-10) } \\
\text { ŁSu-t4 (20-60) }\end{array}$ \\
\hline ŁS I & $\begin{array}{l}\text { Lower glaciofluvial } \\
\text { layer, periglacial } \\
\text { ice-wedge cast at } \\
\text { the top }\end{array}$ & & $\begin{array}{l}\text { Older Warta Stadial } \\
\text { ice-sheet advance }\end{array}$ & $\begin{array}{l}\text { Early Odranian, transgressive, } \\
\text { maximum stadial }\end{array}$ & $\begin{array}{l}2018 \text { ŁSu-f1 (4-10) } \\
\text { ŁSu-f2 (20-60) }\end{array}$ \\
\hline
\end{tabular}

It is worth noting here that only the provenance of indicator erratics is symbolically drawn, in the form of circles, on the schematic maps presented in Figure 2. These rocks were derived from just a single source area in Scandinavia, which is defined by geographical coordinates. Therefore, we cannot determine from the maps whether Scandinavian erratics of limited indicative significance were identified in the examined material or not. Because they could be derived from more than a single source area, or because the area is large, the Scandinavian provenance region for the erratics cannot be visualised. It is therefore necessary to base the interpretation (in Figure 2-in the form of arrows) on the results from comprehensive laboratory analyses.

\section{Results}

4.1. Petrographic Composition of the Medium Gravel Fraction (4-10 mm) from the Łubienica-Superunki Sediments

The petrographic analysis of medium gravel sediments $(4-10 \mathrm{~mm})$ showed that crystalline rocks $(\mathrm{Cr})$ are the most prevalent petrographic type in all samples, regardless of the sediment facies type (Figure 5). The higher percentage of these rocks in the glaciofluvial deposits (unit ŁS III: samples ŁSu-f5 and ŁSu-f6) and glacial till (unit ŁS IV: sample ŁSu-t8) results from the lack of Lower Palaeozoic limestones (LP1) in both these layers.

The image we obtained was the result of mathematical calculations because all components are converted to 100\%. Carbonate rocks occur only in the lower parts of the section, in the glaciofluvial layer (unit ŁS I: sample ŁSu-f1) and in the till (unit ŁS II: sample ŁSu-t3).

It is worth noting that there is a greater percentage of carbonate rocks in the glaciofluvial layer (LP1 39.2\%) than in the till layer (LP1 15.18\%). The proportion of sandstones (S) is variable, but they are present in each layer. Quartz grains $(\mathrm{Q})$ are a similar case; their percentage content varies from $3.8 \%$ to $9.6 \%$. 


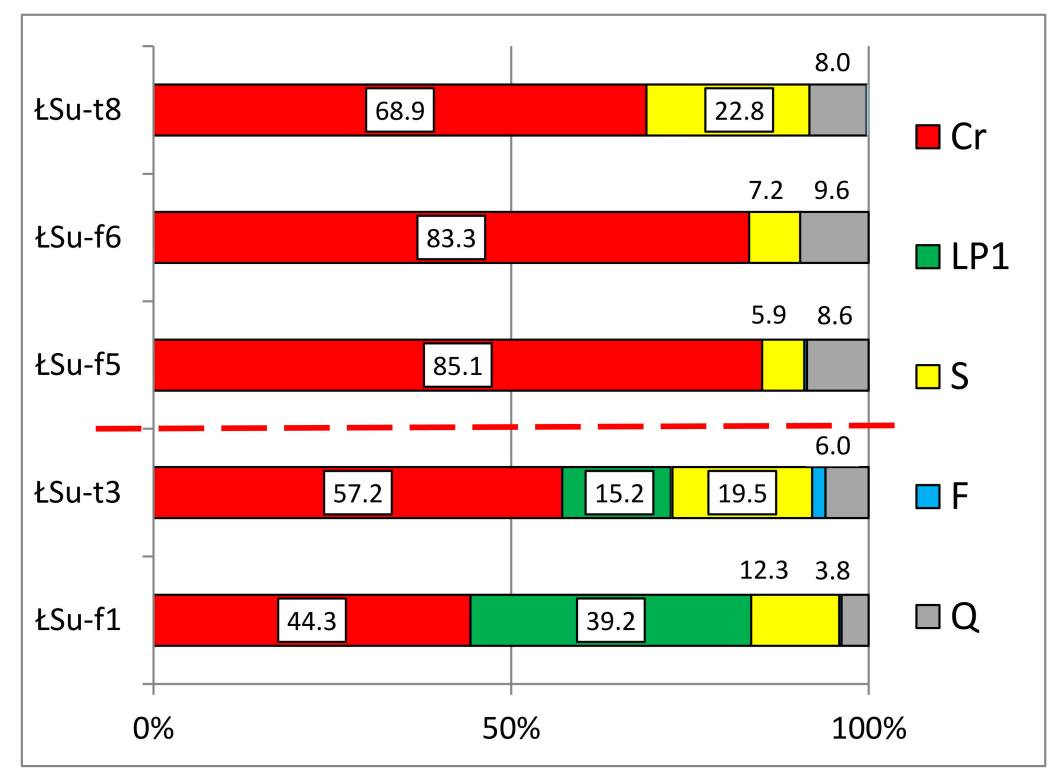

Figure 5. Petrographic composition of 4-10 mm gravels in Łubienica-Superunki. Explanation: for symbols of samples see Table 1; Cr-crystallines, LP1-Lower Palaeozoic limestones (grey), S-sandstones, F-flints, Q-quartz. The red dashed line divides the profile into the lower and upper part.

4.2. Petrographic Composition of the Coarse Gravel Fraction $(20-60 \mathrm{~mm})$ from the Łubienica-Superunki Sediments

The petrographic analysis of coarse gravel fraction $(20-60 \mathrm{~mm})$ showed that crystalline rocks $(\mathrm{Cr})$ are the dominant petrographic type, regardless of the sediment facies type (Figure 6). Their percentage ranges from around 70\% at the bottom of the section to ca. $80 \%$ at the top. It is worth noting that the difference in the percentage of crystalline rocks between the upper till (unit ŁS IV) and the upper glaciofluvial layer (unit ŁS III) is small and was calculated at merely $0.1 \%$. Similarly, the difference between sediments of various facies with respect to the presence of crystalline rocks is up to $1 \%$ in the case of both the lower till (unit ŁS II) and the lower glaciofluvial layer (unit ŁS I).

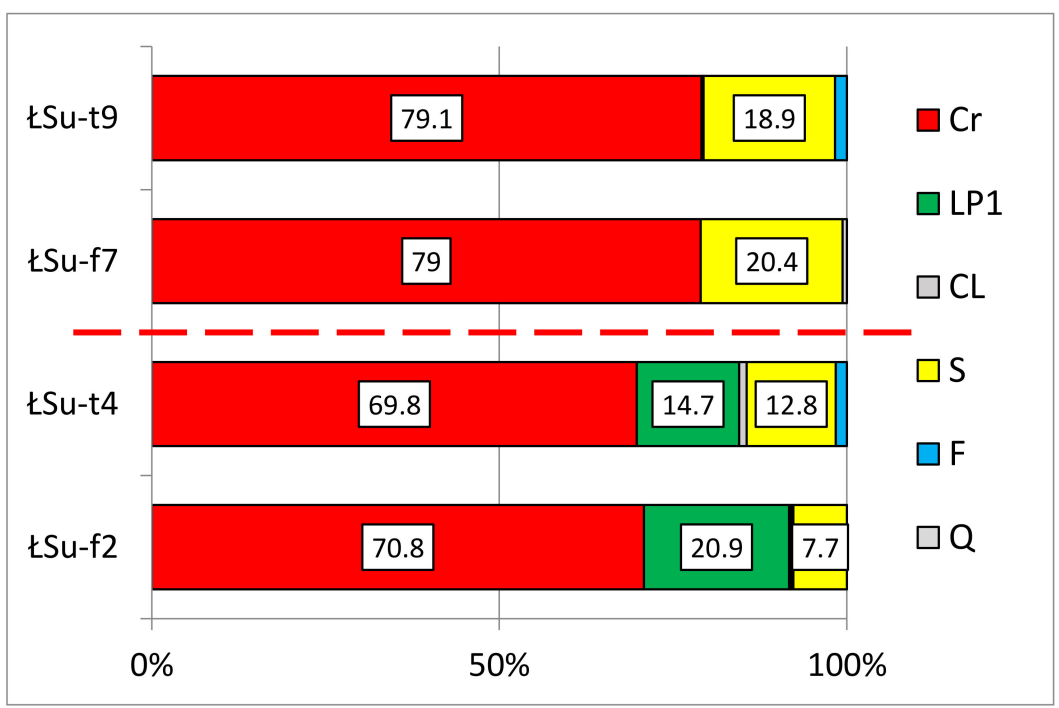

Figure 6. Petrographic composition of 20-60 mm gravels in Łubienica-Superunki. Explanation: for symbols of samples see Table 1; Cr-crystallines, LP1-Lower Palaeozoic limestones (grey), $\mathrm{CL}-$ Cretaceous limestones, $\mathrm{S}$-sandstones, $\mathrm{F}$-flints, $\mathrm{Q}-$ quartz. The red dashed line divides the profile into the lower and upper part. 
Lower Palaeozoic limestones (LP1) and Cretaceous limestones (CL) are found only in the lower layers of the section, in both the till (ŁS I) and glaciofluvial sediments (ES II). Notably, there is a higher percentage of carbonate rocks in the sands and gravels (ESu-f2) than in the till (ŁSu-t4) by $5 \%$. No single carbonate clasts have been found in either of the upper layers. Sandstones (S) are another petrographic type present in all sediment layers studied. Their percentages range from about $7 \%$ to $20 \%$. The large percentage spread is exclusively the result of mathematical calculations. Individual coarse gravels of flints ( $\mathrm{F}$ $1.6-1.7 \%)$ and quartz (Q 0.6\%) were also identified in the analysed layers.

\subsection{Indicator and Auxiliary Scandinavian Erratics of the Coarse Gravel Fraction (20-60 mm) from the Łubienica-Superunki Sediments}

The analysis of coarse gravel fraction from both till layers (ŁS II and ŁS IV; Figure 2) and both glaciofluvial sediment layers (ES I and ŁS III) shows that the most common magmatic indicator erratics were those representing the source area located in the Åland Islands (Table 2).

Table 2. Scandinavian indicator erratics, assigned to the province, of the coarse gravel fraction (20-60 $\mathrm{mm})$ from the Łubienica-Superunki sediments.

\begin{tabular}{|c|c|c|c|c|c|c|c|c|c|c|c|}
\hline \multirow{4}{*}{ Province } & \multirow{4}{*}{ Indicator Erratic } & \multirow{4}{*}{$X$ (Long) E ${ }^{\circ}$ ) } & \multirow{4}{*}{$\mathrm{Y}\left(\right.$ Lat) $\mathrm{N}\left({ }^{\circ}\right)$} & \multicolumn{4}{|c|}{ Lower Units } & \multicolumn{4}{|c|}{ Upper Units } \\
\hline & & & & \multirow{2}{*}{\multicolumn{2}{|c|}{$\begin{array}{c}\text { Unit ŁS I } \\
\begin{array}{c}\text { Sample ŁSu-f2 Outwash } \\
\text { Deposits }\end{array}\end{array}$}} & \multirow{2}{*}{\multicolumn{2}{|c|}{$\begin{array}{c}\text { Unit ŁS II } \\
\text { Sample ŁSu-t4 Till }\end{array}$}} & \multirow{2}{*}{\multicolumn{2}{|c|}{$\begin{array}{c}\text { Unit ŁS III } \\
\begin{array}{c}\text { Sample ŁSu-f7 Outwash } \\
\text { Deposits }\end{array}\end{array}$}} & \multirow{2}{*}{\multicolumn{2}{|c|}{$\begin{array}{c}\text { Unit ŁS IV } \\
\text { Sample ŁSu-t9 Till }\end{array}$}} \\
\hline & & & & & & & & & & & \\
\hline & & & & Pieces & $\begin{array}{l}\text { Total Pieces } \\
{[\%]}\end{array}$ & Pieces & $\begin{array}{l}\text { Total Pieces } \\
{[\%]}\end{array}$ & Pieces & $\begin{array}{c}\text { Total Pieces } \\
{[\%]}\end{array}$ & Pieces & $\begin{array}{c}\text { Total } \\
\text { Pieces [\%] }\end{array}$ \\
\hline \multirow{3}{*}{$\begin{array}{l}\text { Eastern } \\
\text { Fenno- } \\
\text { scandia }\end{array}$} & $\begin{array}{l}\text { Åland granite, Åland rapakivi } \\
\text { and quartz porphyry }\end{array}$ & 20 & 60 & 21 & \multirow{3}{*}{$21(53.9)$} & 18 & \multirow{3}{*}{$26(59.1)$} & 26 & \multirow{3}{*}{$30(51.7)$} & 24 & \multirow{3}{*}{$26(46.4)$} \\
\hline & Red Baltic porphyry & 21.1 & 59.1 & - & & 8 & & 4 & & 1 & \\
\hline & Brown Baltic porphyry & 18.9 & 58.7 & - & & - & & - & & 1 & \\
\hline \multirow{2}{*}{$\begin{array}{c}\text { Central } \\
\text { Sweden (east) }\end{array}$} & $\begin{array}{l}\text { Uppsala granite, Vänge } \\
\text { granite }\end{array}$ & 17 & 59.7 & - & \multirow{2}{*}{$1(2.6)$} & - & \multirow{2}{*}{$0(0)$} & 3 & \multirow{2}{*}{$3(5.2)$} & - & \multirow{2}{*}{$0(0)$} \\
\hline & Stockholm granite & 18 & 59.3 & 1 & & - & & - & & - & \\
\hline \multirow{5}{*}{$\begin{array}{l}\text { Central } \\
\text { Sweden } \\
\text { (west) }\end{array}$} & $\begin{array}{l}\text { Dalarna porhyry, Grönklitt } \\
\text { porhyry }\end{array}$ & 14.5 & 61.5 & 1 & \multirow{5}{*}{$4(10.3)$} & 4 & \multirow{5}{*}{$5(11.4)$} & - & & 3 & \multirow{5}{*}{$12(21.4)$} \\
\hline & Bredvad porhyry & 13.9 & 61.4 & 2 & & - & & 2 & & 8 & \\
\hline & $\begin{array}{l}\text { Blyberg porphyry, other } \\
\text { Dalarna porphyries and } \\
\text { ignimbrites }\end{array}$ & 14.3 & 61.3 & - & & 1 & & - & $2(3.5)$ & - & \\
\hline & Digeberga sandstone & 13.3 & 61.1 & 1 & & - & & - & & - & \\
\hline & Filipstad granite & 13.7 & 60.6 & - & & - & & - & & 1 & \\
\hline \multirow{4}{*}{$\begin{array}{l}\text { Southern } \\
\text { Sweden }\end{array}$} & Västervik quartzite & 16.6 & 57.7 & 4 & \multirow{4}{*}{$13(33.3)$} & - & \multirow{4}{*}{$13(29.6)$} & - & & 5 & \multirow{4}{*}{$18(32.1)$} \\
\hline & Grey Växjö granites & 15 & 57 & - & & 1 & & - & $23(207$ & - & \\
\hline & Småland granites & 15.5 & 57 & 7 & & 12 & & 23 & $23(39.7)$ & 13 & \\
\hline & Kalmarsund sandstone & 16.2 & 56.4 & 2 & & - & & - & & - & \\
\hline \multicolumn{4}{|c|}{ Teoretical boulder center (TBC) } & \multicolumn{2}{|c|}{$59.2^{\circ} \mathrm{N} 18^{\circ} \mathrm{E}$} & \multicolumn{2}{|c|}{$59.1^{\circ} \mathrm{N} 18.2^{\circ} \mathrm{E}$} & \multicolumn{2}{|c|}{$58.8^{\circ} \mathrm{N} 17.9^{\circ} \mathrm{E}$} & \multicolumn{2}{|c|}{$59.4^{\circ} \mathrm{N} 17.3^{\circ} \mathrm{E}$} \\
\hline & Number of total $\mathrm{p}$ & & & & & & & & & & \\
\hline Percer & ge of indicator erratics within co & e gravel rocks in a & mple & & & & & & & & \\
\hline
\end{tabular}

Scandinavian provinces acc. to Lang et al. [30] and other references, listed therein; TBC calculated acc. to Lüttig [5].

The Åland granite and the Åland quartz porphyry were more frequent in both upper layers (ŁS III and ŁS IV). Together with the red and brown Baltic porphyry, they formed on average a few percent more compared to sediment samples from lower levels. Similarly, these layers contained more (ca. 5-10\%) indicator erratics from southern Sweden as compared to the lower layers. These were primarily the Småland quartz porphyry and the Småland granite, but the Västervik quartzite and the Växjö grey granite were also found. In the upper till and the upper glaciofluvial layer, indicator erratics from central (west) Sweden (from the source area of Dalarna), i.e., the Bredvad porphyry and the Grönklitt porphyry, were more numerous than in the lower layers. One specimen of the Digerberg sandstone was also identified, being the indicator erratic of sedimentary origin.

In contrast, sedimentary erratics of limited indicative significance, originating from outcrops located in the Baltic floor (Figure 7), were identified only in the lower units (ŁS I and ŁS II). These were mainly Lower Palaeozoic grey limestones (ca. 15-20\%), 
with numerous (ca. 3-4\%) specimens of red Jotnian sandstone, and single pieces of red Ordovician limestone and the Palaeoporella limestone.
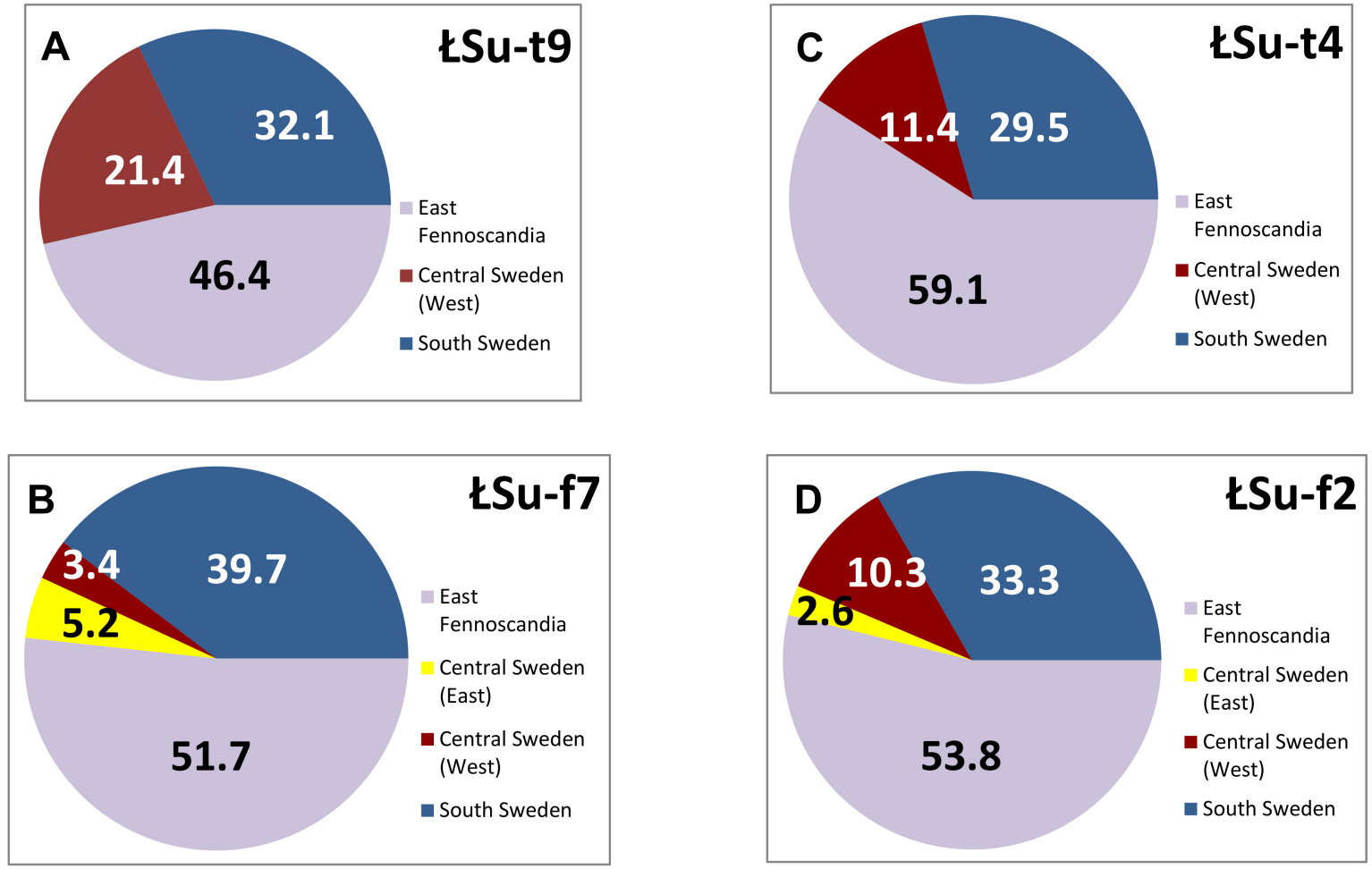

Figure 7. Erratics provenance of two lower $(\mathbf{D}, \mathbf{C})$ and two upper $(\mathbf{B}, \mathbf{A})$ units. The provinces are based on Lang et al. [30] and references therein. The numbers are shown as a percentage.

\section{Discussion}

Detailed petrographic studies of medium- and coarse-grained gravels in sediments of the Middle Polish Glaciations (Middle Polish Complex acc. to Marks [69], Marks et al. [92] and Nitychoruk et al. [43]) shed new light on the problem of the Scandinavian origin of sediments in this part of Europe.

It is difficult to take into account earlier petrographic studies of the gravel fraction in this region, both to establish the chronostratigraphy of glacial/glaciofluvial deposits and the provenance of ice sheets. The upper sandy till [79,93], assigned by Nowak [79] to the Wierzbica Phase of the North Mazovian Stadial of the Middle Polish Glaciations, petrographically investigated, presents results that are incomparable with the results obtained by the present authors, because the identified petrographic groups are different. They can be treated only in illustrative terms.

The results of petrographic analyses of the medium grain gravels in tills discussed in this article, can be compared firstly with the results of analyses carried out for the construction of the DGMP, 1:50,000 scale, Serock sheet (No 450; Frankiewicz [76]) and Wyszków sheet (No 451; Kucharska \& Pochocka-Szwarc [78]), i.e., the area adjacent to the study site.

The petrographic composition of medium-grain gravel $(4-10 \mathrm{~mm})$ from the lower till is characterised by the predominance of Palaeozoic limestones over crystalline rocks, both within the Serock sheet (Marcinkowski's study [94]) and the Wyszków sheet (Zabielski's study [77]).

Both authors suggest correlating this till with the Middle Polish Odra Glaciation (Stadial). Our research in Łubienica-Superunki indicates an almost four-times higher share of crystalline rocks than of limestones in this till (ŁS II: ŁSu-t3; Figure 5).

The upper till was examined only for the Wyszków sheet [78], where Zabielski [77] also reported the prevalence of Lower Palaeozoic limestones over crystalline rocks; although, the author admits that the dominance was not clear. Based on the research, he correlates this 
with the Middle Polish Warta Glaciation (Stadial). The present petrographic research carried out in Łubienica-Superunki indicates a lack of carbonate rocks among the 4-10 mm gravel from the upper till (ŁS IV: sample ŁSu-t8), as well as from the underlying glaciofluvial layer (ŁS III: samples ŁSu-f5, ŁSu-f6).

Glaciofluvial deposits were also covered by petrographic analyses. The study results, separately for the lower and upper parts of the section, were very similar to those from till beds. The lower glaciofluvial deposits (unit I) show a greater (39.24\%) percentage of carbonate rocks than the lower till (unit II; 15.18\%). Both the upper glaciofluvial level and the till display no carbonate rock content.

Two samples (ŁSu-f5 and ŁSu-f6) from upper glaciofluvial deposits (unit III) display almost the same percentage of gravel belonging to a given petrographic type. The much greater variability in the percentage of petrographic types of gravel (between different-age sediments) in the vertical section compared to within one sedimentary unit can support chronostratigraphic inference. Such a procedure was used, for example, in the case of Pleistocene tills of various ages in Ujście on Noteć $[25,95]$.

The petrographic studies of medium grain gravels of four lithologically variable sedimentary units in Łubienica-Superunki provide the basis for an attempt to separate the two lower sedimentary units (ŁS I and ŁS II) from the two upper ones (ŁS III and ŁS IV). They were discriminated by the presence of carbonate rocks in both lower units and their absence in the upper ones. Therefore, on this basis, it can be concluded that the ice sheet took a different path. The older ice sheet must have advanced upon the outcrops of sedimentary rocks in the Baltic Sea basement (Figure 8).
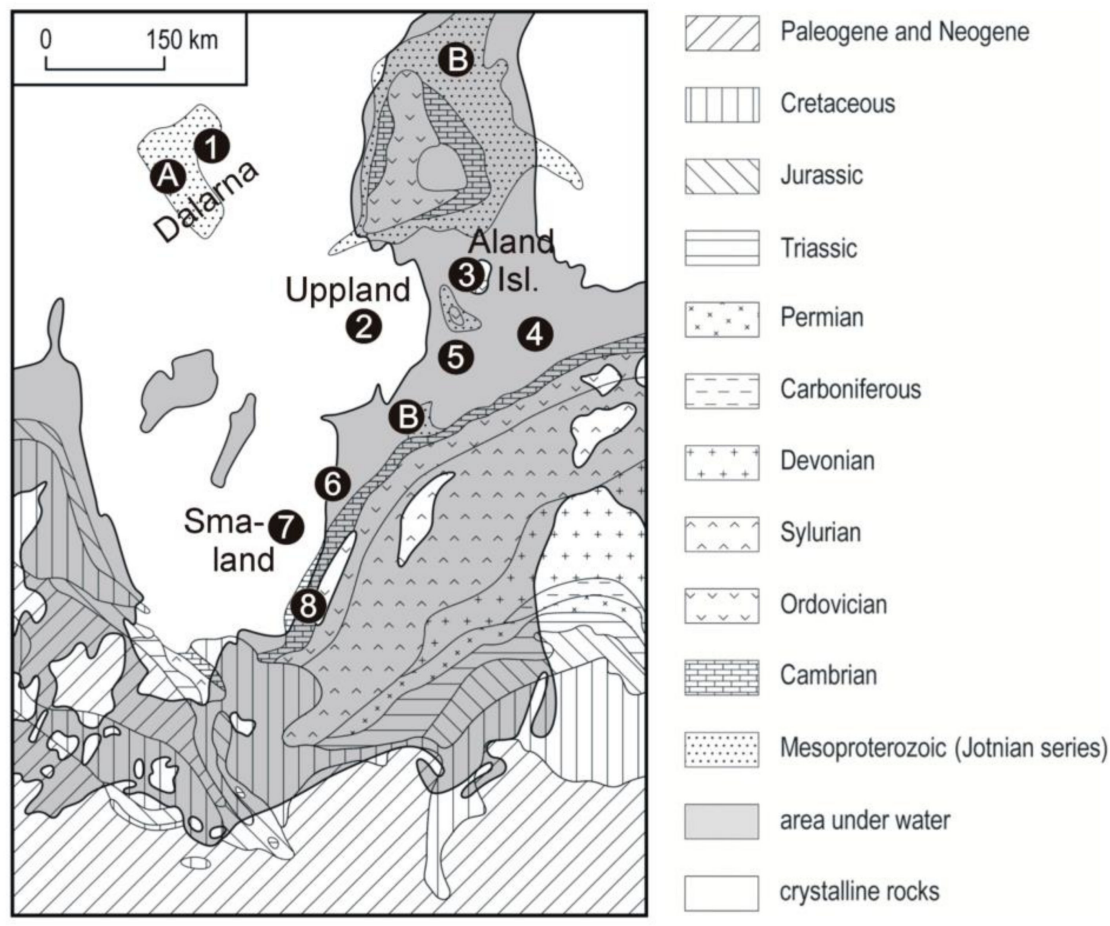

Figure 8. Location of the outcrops of indicator erratics, identified in the Łubienica-Superunki gravel pit, and symbolic location of the outcrops of erratics of limited indicative significance. Symbols of indicator erratics: 1-Bredvad porphyry, 2-Uppsala granite, 3-Åland quartz porphyry, 4-red Baltic porphyry, 5-brown Baltic porphyry, 6-Västervik porphyrite, 7-Småland granite, 8-Kalmar and Tessini sandstones. Symbols of erratics of limited indicative significance: A-Dalarna sandstone, B-Jotnian sandstone.

The lack of Lower Palaeozoic limestones in both upper sedimentary units may indicate that part of the cold basal ice layer, attached to the ground and not having exarative ability, was in the area of their Scandinavian outcrops. The lack of these rocks may be due not only 
to the effect of part (stream) of the ice sheet not moving upon these outcrops, but also the consequence of weathering of carbonate rocks in the near-surface layers (units ŁS III and ŁS IV). It is difficult to exclude any of these premises.

The usefulness of glaciofluvial sediments for petrographic studies has been previously noted $[16,29,40,62,63,65,67]$. The research in Łubienica-Superunki fully confirmed this [96]. Glaciofluvial sediments may provide additional support in litho-stratigraphic studies.

Sampling of tills, involving methodical recommendations, is a time-consuming procedure [40]. Since it has been demonstrated that the percentages of petrographic types of gravel do not differ between the till and the glaciofluvial sediments, it is recommended that the tedious collecting of boulders for this analysis from the till be replaced by collecting them instead from the sand-gravel layer, which is a much easier and faster process. The author of this study has come to similar conclusions by examining sediments in northwestern Poland and north-eastern Germany [29]. Studies from central Poland [40,52] also seem to confirm this conclusion, providing a picture of the petrographic diversity of rock types between sediments of different ages.

The petrographic analyses also showed that the lithological type does not determine the presence or absence of carbonate rocks in the gravel inventory. These rocks were present in both the lower till (sample ŁSu-t3; Figure 5) and the lower glaciofluvial layer (ŁSu-f1). Moreover, the discussed segregation of gravel grains by flowing water [53] and their weathering [57] in glaciofluvial sediments was not confirmed by our research. We are of the opinion that the occurrence of carbonate rocks, irrespective of the lithogenetic type of sediment from which they originate, is a consequence of ice-sheet movement upon the Lower Palaeozoic outcrops in the bottom of the Baltic Proper. There are examples in the literature proving the usefulness of glaciofluvial sediments in petrographic analyses $[16,62,63,65,67]$. This issue, with reference to appropriate sources, is widely discussed in Górska-Zabielska [45].

The results of the petrographic analyses of medium grain gravels are reflected in the results of such analyses of coarse gravel fractions, taking into account the regularities $[19,95]$ in the percentage of petrographic types between both fractions, which is known from the literature. Gravels from both lower units (ŁS I, ŁS II) included Lower Palaeozoic limestone (LP1). Their percentage content was greater in the sediments that were subject to grain segregation by water ( $€ S u-f 2)$ than in the till (ŁSu-t4). Both upper units ( $€ S$ III, ŁS IV) were deprived of these rocks. The percentages of gravels of individual petrographic types in different lithogenetic types were almost identical (ŁSu-f7, ŁSu-t9; Figure 6).

The Scandinavian erratics of the $20-60 \mathrm{~mm}$ fraction point to the exarative ability of ice sheets of both advances in the Åland Islands and in the outcrops located at a distance of approximately $1^{\circ}$ southeast of the islands, i.e., outcrops of the Baltic red porphyry (Figure 8). The older ice sheet moved upon the Lower Palaeozoic outcrops of the Baltic basement (Figure 8) more strongly than the younger one (Figure 7C,D). All of these mother regions are located in the eastern Fennoscandia. Similar conclusions, based on the study of sediments in central Poland, have recently been reached by Czubla et al. [51] and Strzelecki [42]. They claim that a characteristic feature of the Odranian Glaciation in the indicator and auxiliary (of limited indicative significance) erratics is the high proportion of Aland and Baltic rocks and the small proportion of rocks from SE and central Sweden. The high proportion of rocks from eastern Fennoscandia indicates that this is a common feature of sediments from the Middle Polish Glaciation Complex. Studies by Lang et al. [30] on older deposits of the Saalian Complex, carried out on the border of northern Germany and the Netherlands, also indicate a predominance of erratics from the source area of eastern Fennoscandia.

In contrast, the ice sheet of the younger advance, which reached Łubienica-Superunki, exarated the outcrops of south-eastern Sweden more strongly (Figure 7A,B). Assemblages of indicator erratics of all units contain erratics from central Sweden. Their quantity, although much smaller than of the abovementioned, should be noted as a point of order. 


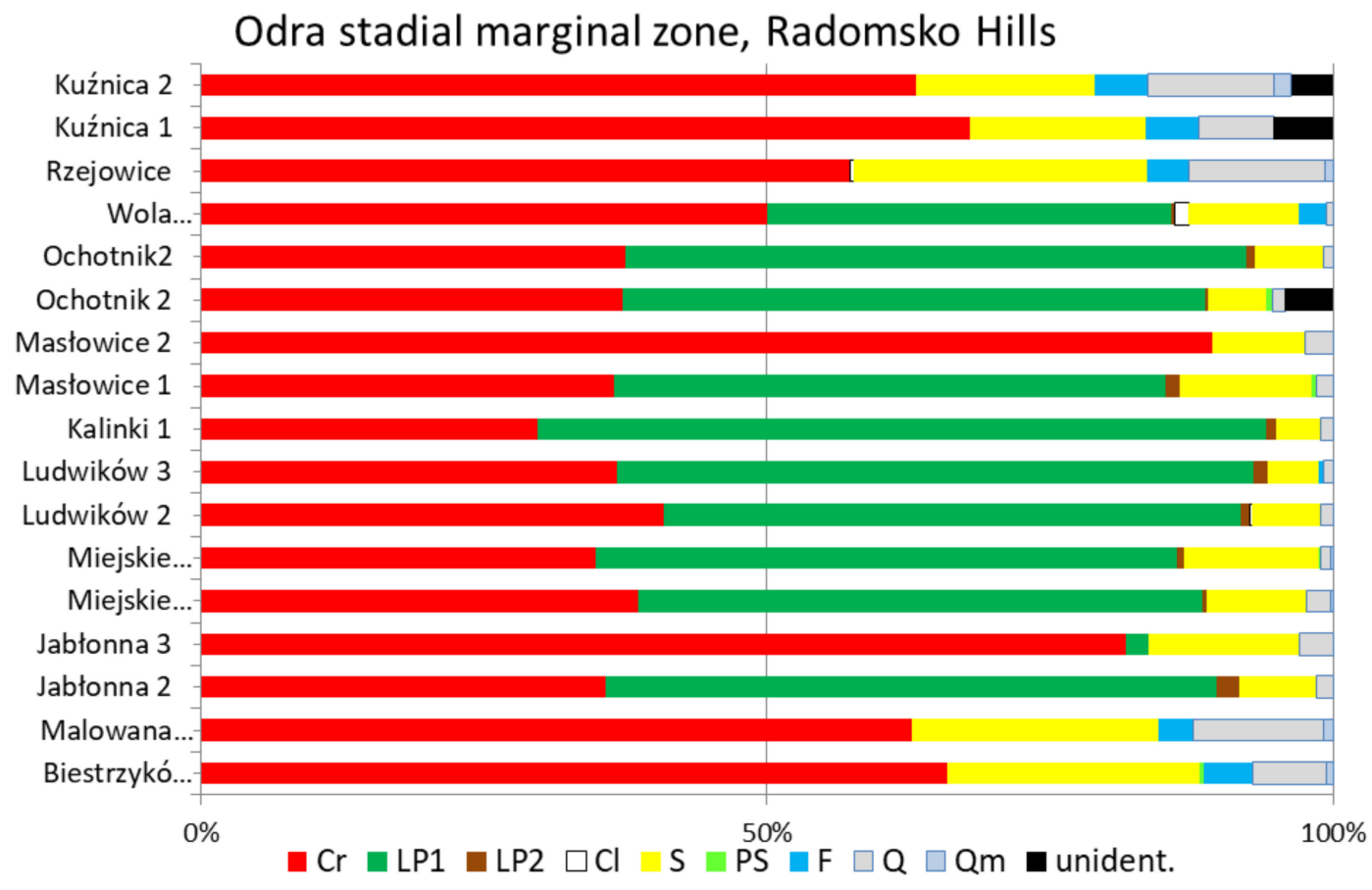

(A)

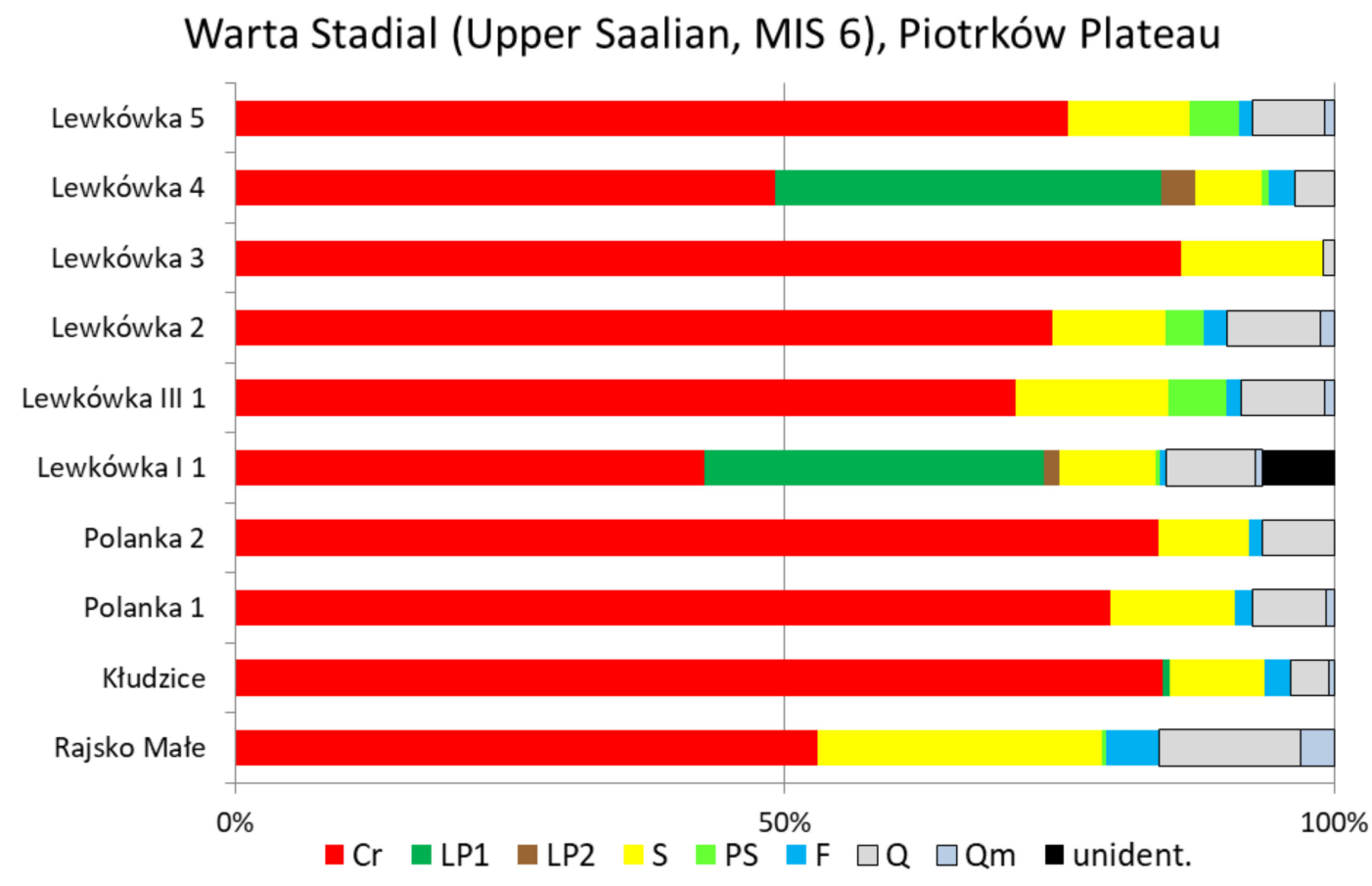

(B)

Figure 9. Percentages of the petrographical groups of the glaciofluvial gravels within the marginal zone (A) correlated with the Odra Stadial, and its hinterland (B) correlated with the Warta Stadial (Upper Saalian, MIS 6). Source: Górska-Zabielska and Wachecka-Kotkowska [37]. Symbols explanation: Cr—crystalline, LP1—grey Lower Palaeozoic limestones, LP2—red Lower Palaeozoic limestones, $\mathrm{Cl}$-Cretaceous limestones, S—sandstones, PS-Palaeozoic shales, F-flints, Q-quartz, Qm-milk quartz, unident—unidentified.

The authors obtained similar results for the lithopetrographic bipartition of near-surface sediments in the marginal zone and in the hinterland of the maximum limit of the Warta 
Stadial in the Przedbórz Upland, Radomsko Hills and Piotrków Plain, south of Łódź, central Poland $[40,52,70]$ (see Figure 1A). Gravels from the glaciofluvial deposits of the marginal zone, correlated with the Odra Stadial, included Lower Palaeozoic limestones (Figure 9A), while the gravels from the glaciofluvial sediments of the hinterland, correlated with the Warta Stadial (Upper Saalian, MIS 6), were basically devoid of these rocks (Figure 9B).

It is worth noting that the older deposits from Eubienica, identified with the Odranian Glaciation, and the oldest ones from NW Germany [30] indicate the same source areas, so, the exaration area covered the eastern part of Fennoscandia. The route of the longdistance transport by the ice sheet was meridional N-S (arrows in Figure 2). Czubla and Sokołowski [71] suggest that the probable course of the Late Saalian was along the present-day Swedish coast and it turned to the east in the final stage. Although they confirm "a slight predominance of sedimentary rocks over crystalline rocks" after finegravel petrographic analyses, they believe that there was no equivalent of a Baltic ice stream in the Penultimate Glacial Maximum (meaning Punkari [97]).

Younger deposits from Łubienica indicate that the ice-sheet advance path changed from meridional to NE-SW (arrows in Figure 2). This means that the exarative activity of the ice sheet influenced other regions, located more to the west, of the Baltic Shield. In the change in the direction of the transgression of the younger ice sheet, we see the same tendency mentioned by Ehlers [98], who claims that the glaciation centres of the succeeding ice-sheets moved eastwards.

The theoretical boulder centre (TBC) (TGZ = Theoretisches Geschiebezentrum [5]) is a measure that enables comparing the levels of glacial deposits containing indicator erratics. It is a mathematically calculated pair of coordinates, being the weighted average of all indicator erratics identified in a sample. It should be strongly emphasised that it does not indicate an exaration zone, because it is based, for methodological reasons, solely on indicator erratics and does not include auxiliary ones.

Figure 10 shows the location of the calculated TBCs for the sediments we studied at Łubienica-Superunki. Erratics of the two lower lithologically variable levels of sediments are similar to each other in terms of the TBC. The TBC location varies within the geographic latitude/longitude limits of $0.2^{\circ}$ (i.e., about $15 \mathrm{~km}$ along a straight line).

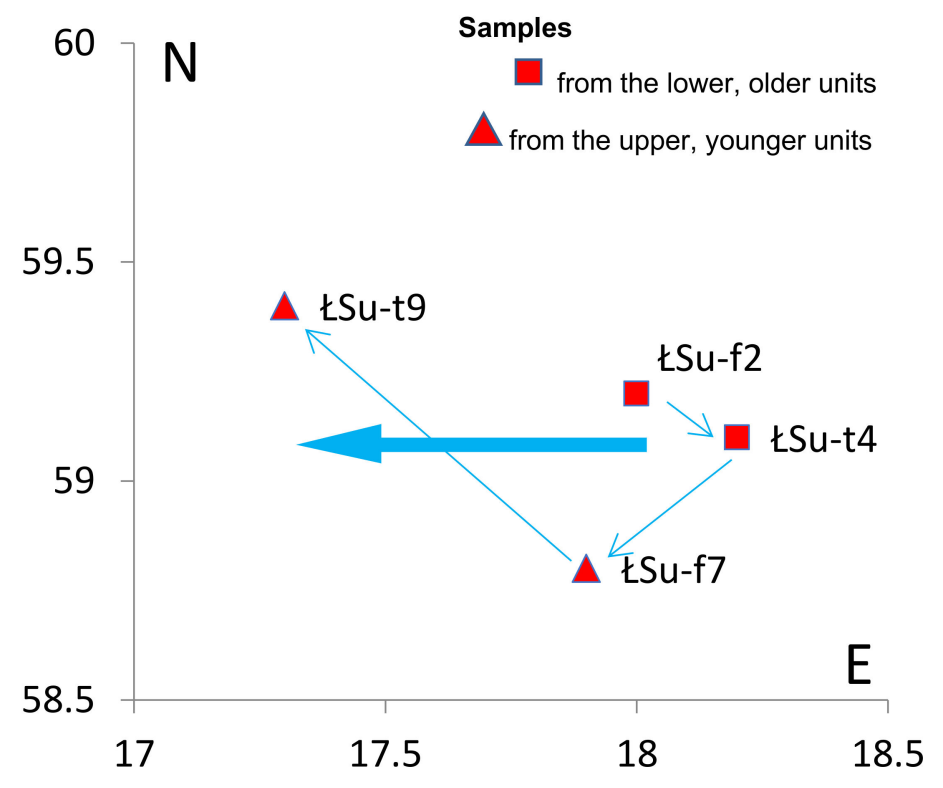

Figure 10. Theoretical boulder centres of indicator erratics from Łubienica-Superunki. The arrows show the shift of TCBs from the younger layer towards the upper one. The resultant shift is also shown. 
The TBC erratics of the upper levels are quite spaced apart (i.e., about $75 \mathrm{~km}$ along a straight line). The shift of $Ł S U-t 9$ (from glacial till) to the northwest is the result of a large number of erratics from Dalarna (central Sweden), and the southernmost location (compared to the other three samples) of ŁSu-f7 (from glaciofluvial deposits) is the result of the largest number of erratics from SE Sweden, from Småland, in that sample.

It is worth noting that the resultant shift in the TBC from older sediments is moved to the west in relation to the TBC from younger sediments (Figure 10). The thesis of Ehlers [98] that the younger the glaciation, the more its centre moves eastwards, is not supported in our research. This thesis is also not confirmed by research in central Poland. TBCs of younger sediments in Łubienica-Superunki are closer to sediments of Wartanian (Middle Saalian) age [33].

Figure 11 summarises the TBC calculated for the Middle Polish and older tills from the territory of Poland, as cited in the literature.

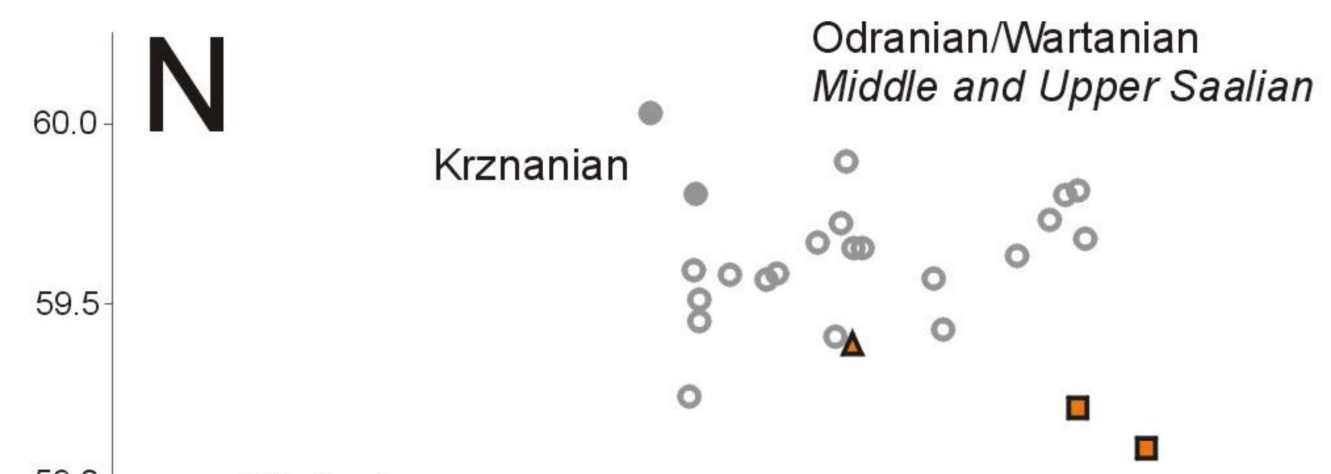

Wartanian Upper Saalian
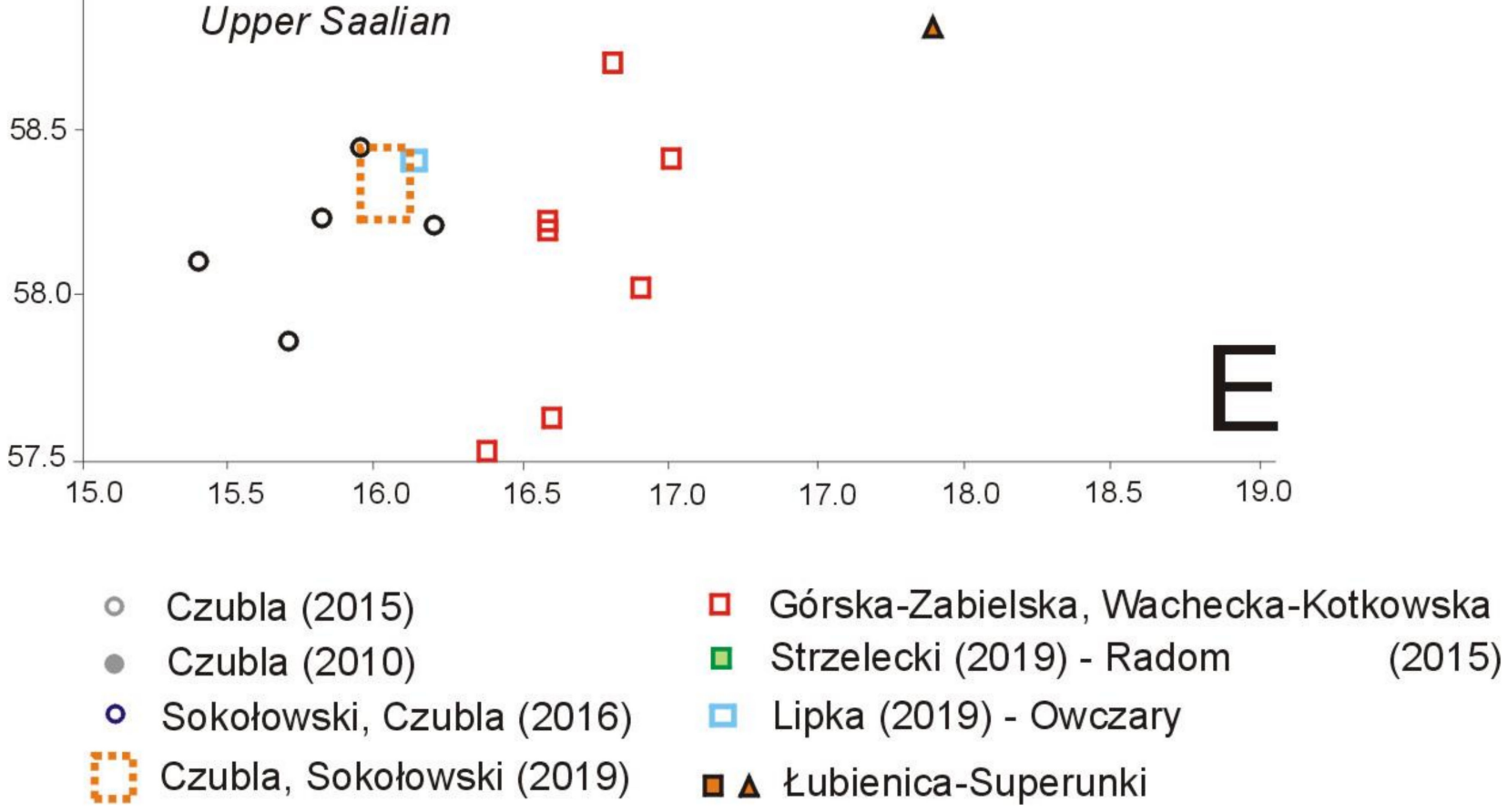

Figure 11. Theoretical boulder centres (TBC) of indicator erratics in Łubienica-Superunki against others calculated in central Poland by listed authors, according to certain ice sheet advances. Krznian-MIS8, Odranian/Wartanian-MIS6.

These data shows that the sediments deposited during the Middle Polish Glaciation (Middle and Upper Saalian) show slight differences in the position of the TBCs during the two glacial episodes of stadial rank - the Odra and Warta maximum stadials (see Figure 1).

However, the lower part of the sediments (units ŁS I and ŁS II) is characterised by similar TBCs and the TBCs for the upper LS IV unit are slightly distant (Figure 10), while 
sediments from Łubienica-Superunki are characterised by TBCs located close to TBCs representing Odranian/Warthanian glaciation (Figure 11). Additionally, petrographic features of medium-grained gravels and differentiation in terms of indicator erratics, i.e., the direction of long-distance glacial transport, suggest linking the LSIII and LSIV units rather than the younger glacial episodes-Warthanian. The slight remoteness of the location of TBCs may be due to the interlobate nature of the glaciation in those Scandinavian magmatic source regions, which were eroded by the ice-sheet that deposited its erratics in Łubienica-Superunki. The interlobate area during ice-sheet advance (palaeo-ice streams?) was confirmed by Marks et al. [92]. After leaving central Sweden, the ice sheet spread widely to the south/southeast.

The two till beds identified at Łubienica-Superunki in the North Mazovian Lowland and their position indicate that it is the Warthe/Drenthe in the Global Chronostratigraphical Correlation Table for the last 2.7 million years [91], i.e., the Warta and Odra Stadials according to Marks [69] and Marks et al. [92]. These beds correspond to two remarkable cold fluctuations of stadial rank $[99,100]$ and were additionally accentuated by a horizon of epigenetic wedges [75] just before the advance of the Middle Polish ice sheet of the Odra Stadial [31,43]. Thus, our current research (Figure 12) demonstrates a clear separation of the two Saalian stadials.

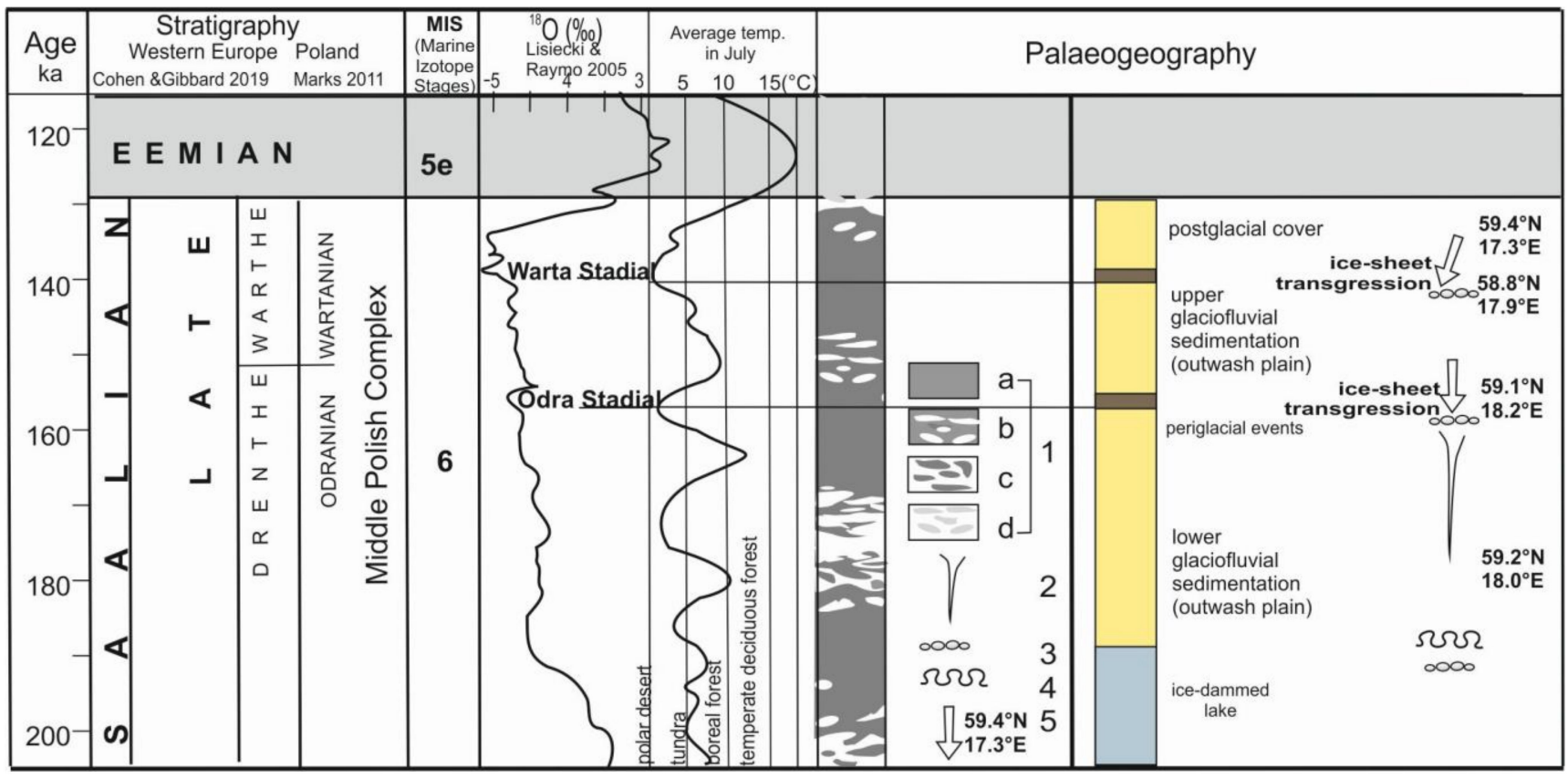

Figure 12. Formation of the glacial and glaciofluvial deposits in Łubienica-Superunki, central Poland, against the stratigraphy and the chosen environmental features during Late Saalian in Europe Legend: 1-type of permafrost: a-continuous, b-discontinuous, c - sporadic, d-seasonal, 2-ice wedge, 3-erosional pavement, 4-direction of the ice sheet movement generated on the basis of complex petrographic analysis, 5-TBC.

\section{Conclusions}

The petrographic analysis was performed on medium- and coarse-grained gravels exposed in two till layers and two layers of glaciofluvial sediments, presumed to have been deposited during the Saalian (MIS6, Middle Polish Glaciations) at the boundary of the Lower Narew Valley and the Ciechanów Plateau within the North Mazovian Lowland. The following regularities were found:

- The similarity of the percentages of gravels of the same petrographic types allows the correlation of the two lower units (ŁS I and ŁS II) with a single ice-sheet advance, and the two upper units (ŁS III and ŁS IV) with another, separate ice-sheet transgression; depending on the lithogenetic type, it would be its stand-still, or recession, or sediment 
deposition, indicating the approach of the next ice sheet. This regularity refers to both grain factions;

- The small variability in the percentages of gravels of the same petrographic type between different lithogenetic types suggests we can give up the tedious sampling of glacial till to focus on a much faster petrographic analysis of glaciofluvial sediments associated with the same ice sheet. This pattern manifests itself more clearly among coarse gravels;

- The lower till (ES II) and the lower layer of glaciofluvial sediments (ŁS I) are characterised by the presence of Palaeozoic limestones; their percentage share is greater in the glacial environment sediments, irrespective of the grain fraction tested;

- Both upper sedimentary units (ŁS III and ŁS IV) in both tested fractions are devoid of carbonate rocks;

- Crystalline rocks dominate in all the sedimentary units under study, both in the medium- and coarse-gravel fractions;

- The percentage of quartz grains is noticeably higher among finer gravels;

- Theoretical boulder centres (TBCs) are located a short distance from each other, which may indicate that indicator erratics might have been eroded within the interlobate area during ice-sheet advance. Regardless, it is worth noting that TBCs moved from an area located within $59.1-59.2^{\circ} \mathrm{N}$ and $18.0-18.2^{\circ} \mathrm{E}$ for lower, older units towards an area located to the south and west (58.8-59.4 $4^{\circ} \mathrm{N}$ and 17.3-17.9 $\mathrm{E}$ ) for upper, younger ones;

- The calculated TBCs for the sediments from Łubienica-Superunki, against the background of the existing data from Poland (Figure 11), indicate that these sediments belong to the older part of the Odranian/Wartanian glaciation, especially in those studies that concern the petrographic analysis of sediments of the Wartanian (Middle Saalian) age.

The results of petrographic analyses point to the duality of the ice sheet advanceolder (Odranian - units ŁS I and II) and younger (Wartanian- units ŁS III and IV) stadials of the Middle Polish Complex (Saalian, MIS 6) and a shift of the TBC within this ice advance towards the south and north-west.

Using the previous age correlation of sediments from the study area and based on other pan-regional studies, at the current stage of research, we lean towards the thesis that the part of the ice stream of the Odra maximum Stadial (Odranian, Middle Polish Complex) that reached the study area advanced upon the outcrops of the Åland Islands and the immediate surroundings, in the floor of the Baltic, barely touching the present-day southeastern coast of Sweden (Figure 8). The younger ice sheet of the Warta Stadial (Wartanian) of that glaciation developed its exarative ability mainly in the Åland Islands, and in central and south-eastern Sweden. The lack of rocks from the bottom of the Baltic Sea may suggest that the Wartanian ice stream bypassed them, or it is evidence that some of its fragment (the one that moved upon the Lower Palaeozoic outcrops) had a cold base Weathering of sediments cannot be excluded. This last explanation is, however, questionable in light of the results of petrographic studies conducted on the Wyszków sheet of the DGMP, 1:50,000 scale.

Author Contributions: Conceptualisation E.S., L.W.-K. and M.G.-Z.; investigation E.S., L.W.-K. and M.G.-Z.; methodology M.G.-Z.; formal analysis M.G.-Z.; software and data curation M.G.-Z.; writing—draft M.G.-Z.; writing—review \& editing E.S. and L.W.-K.; visualisation E.S., L.W.-K. and M.G.-Z.; preparing the references with Zotero L.W.-K. This study results from independent basic research at the authors' organizations and institutions. All authors have read and agreed to the published version of the manuscript.

Funding: This research received no external funding.

Data Availability Statement: Not Applicable.

Acknowledgments: Our gratitude goes to family members who helped us with the field work. We thank the anonymous referees for their constructive commentary and many insightful comments and suggestions. 
Conflicts of Interest: The authors declare no conflict of interest.

\section{References}

1. Milthers, V. Scandinavian Indicator Boulders in the Quaternary Deposits. Danmarks Geoloigske Undersøgelse II 1909, 23, 1-153.

2. Korn, J. Die Wichtigste Leitgeschiebe Der Nordischen Kristallinen Gesteine Im Norddeutschen Flachlande; Preuß. Geol. Landesanstalt: Berlin, Germany, 1927.

3. Hesemann, J. Zur Petrographie Einiger Nordischer Kristalliner Leitgeschiebe. Abh Preuss. Geol Landesanst 1936, NF173, 1-167.

4. Hesemann, J. Kristalline Geschiebe Der Nordischen Vereisungen; Geological State Office: Reston, VA, USA, 1975.

5. Lüttig, G. Methodische Fragen Der Geschiebeforschung. Geol. Jahrb. 1958, 75, 361-418.

6. $\quad$ Smed, P. Sten i Det Danske Landskab; Geografforlaget: Odense, Denmark, 1989.

7. Zandstra, J.G. Platenatlas van Noordelijke Kristalijne Gidsgesteenten; Backhuys Publishers: Leiden, The Netherlands, 1999.

8. Milthers, V. Die Verteilung Skandinavischer Leitgeschiebe Im Quartär von Westdeutschland. Abh. Preußischen Geol. Landesanst. 1934, 156, 1-74.

9. Milthers, V. Geschiebeuntersuchungen Und Glazialstratigraphie. Z. Dtsch. Geol. Ges. 1937, 88, 115-120.

10. Meyer, K.-D. Indicator Pebble and Stone Count Methods. In Glacial deposits in North-West Europe; Ehlers, J., Ed.; Balkema: Rotterdam, The Netherlands, 1983; pp. 275-287.

11. Meyer, K.-D. Zur Entstehung Der Westlichen Ostsee. Geol. Jahrb. 1991, A127, 429-446.

12. Bourchard, M.A.; Salonen, V.-P. Glacial Dispersal of Boulders in the James Bay Lowlands of Quebec, Canada. Boreas 1989, 18, 89-199.

13. Bourchard, M.A.; Salonen, V.-P. Boulder Transport in Shield Areas. In Glacial Indicator Tracing; Kujansuu, R., Saarnisto, M., Eds.; Balkema: Rotterdam, The Netherlands, 1990; pp. 87-107.

14. Dyke, A.S.; Morris, T.F. Drumlin Fields, Dispersal Trains and Ice Streams in Arctic Canada. Geographer 1988, 32, 86-90. [CrossRef]

15. Lüttig, G.; Meyer, K.-D. Geschiebezählungen in Der Nördlichen Lüneburger Heide. Geschiebesammler 2002, 34, 155-172.

16. Lüttig, G. Geschiebezählungen Im Westlichen Mecklenburg. Arch. Geschiebekd. 2005, 4, 569-608.

17. Salonen, V.-P. Glacial Transport Distance Distribution of Surface Boulders in Finland. Geol. Surv. Finl. Bull 1986, $338,1-57$.

18. Schulz, W. Rhombenporphyr-Geschiebe Und Deren Östliche Verbreitungsgrenze Im Nordeuropäischen Vereisungsgebiet. Z. Geol. Wiss. 1973, 9, 1141-1154.

19. Schulz, W. Sedimentäre Findlinge Im Norddeutschen Vereisungsgebiet. Arch. Geschiebekd. 1999, 2, 523-560.

20. Schulz, W. Geologischer Führer Den Norddeutschen Geschiebesammler; CW Verlagsgruppe Schwerin: Schwerin, Germany, 2003.

21. Shilts, W.W. Glacial Dispersal of Rocks, Minerals and Trace Elements in Wisconsian till, Southeastern Quebec, Canada. In The Wisconsian Stage; Black, R.B., Goldthwait, R.P., William, H.B., Eds.; Memoir; Geological Society of America: Boulder, CO, USA, 1973; pp. 189-219.

22. Shilts, W.W. Glacial Dispersal-Principles and Practical Applications. Geosci. Can. 1982, 9, $42-47$.

23. Vinx, R. Hochauflösende Rekonstruktion von Eistransportwegen: Die "Leitserienmethode". Arch. Geschiebekd. 1993, 1, 625-640.

24. Vinx, R. Gesteine Des Baltisches Schildes in Nordeutschland: Glazialgeschiebe an Der Ostseeküste von Schleswig Und NWMecklenburg. Beih. Zum Eur. J. Mineral. 2002, 14, 219-242.

25. Böse, M.; Górska, M. Lithostratigraphical Studies in the Outcrop at Ujście, Torun-Eberswalde Pradolina, Western Poland. Eiszeitalt. Ggw. 1995, 45, 1-14.

26. Lüttig, G. Ergebnisse Geschiebestatistischer Untersuchungen Im Umland von Hamburg. Arch. Geschiebekd. 2004, 3, 729-746.

27. Meyer, K.-D. Geschiebekundlich-Stratigraphische Untersuchungen in Der Südlichen Lüneburger Heide. Mitt. Geol. Inst. Univ Hann. 1998, 38, 178-188.

28. Meyer, K.-D. Geschiebekundlich-Stratigraphische Untersuchungen Im Hannoverschen Wendland (Niedersachsen). Brand. Geowiss. Beitr. 2000, 7, 115-125.

29. Górska-Zabielska, M. Fennoskandzkie Obszary Alimentacyjne Osadów Akumulacji Glacjalnej i Glacjofluwialnej Lobu Odry; Wydawnictwo Naukowe UAM: Poznań, Poland, 2008.

30. Lang, J.; Lauer, T.; Winsemann, J. New Age Constraints for the Saalian Glaciation in Northern Central Europe: Implications for the Extent of Ice Sheets and Related Proglacial Lake Systems. Quat. Sci. Rev. 2018, 180, 240-259. [CrossRef]

31. Meyer, K.-D. Zur Stratigraphie Des Saale-Glazials in Niedersachsen Und Zu Korrelationsversuchen Mit Nachbargebieten. EEG Quat. Sci. J. 2005, 55, 25-42. [CrossRef]

32. Czubla, P. Eratyki Fennoskandzkie w Polsce Środkowej i Ich Znaczenie Stratygraficzne. Acta Geogr. Lodz. 2001, 80, 1-174.

33. Czubla, P. Eratyki Fennoskandzkie w Osadach Glacjalnych Polski i Ich Znaczenie Badawcze (in Polish); Wydawnictwo Uniwersytetu Łódzkiego: Łódź, Poland, 2015.

34. Gałązka, D. Zastosowanie Makroskopowych Badań Eratyków Do Określenia Stratygrafii Glin Lodowcowych Środkowej i Północnej Polski. Ph.D. Thesis, Archiwum Wydziału Geologii UW, Warsaw, Poland, 2004. (In Polish).

35. Górska, M. Petrografia Osadów Akumulacji Lodowcowej i Wodnolodowcowej Pojezierza Drawskiego (in Polish with English Summary). Badania Fizjograficzne nad Polska Zachodnia 2002, 53, $29-42$.

36. Woźniak, P.P.; Czubla, P. The Late Weichselian Glacial Record in Northern Poland: A New Look at Debris Transport Routes by the Fennoscandian Ice Sheet. Quat. Int. 2015, 386, 3-17. [CrossRef] 
37. Woźniak, P.P.; Czubla, P. Unravelling the Complex Nature of the Upper Weichselian till Section at Gdynia Babie Doły, Northern Poland. Geologos 2016, 22, 15-32. [CrossRef]

38. Woźniak, P.P.; Sokołowski, R.J.; Czubla, P.; Fedorowicz, S. Stratigraphic Position of Tills in the Orłowo Cliff Section (Northern Poland): A New Approach. Stud. Quat. 2018, 35. [CrossRef]

39. Czubla, P.; Forysiak, J. Pozycja Stratygraficzna Gliny w Besiekierzu Koło Łodzi w Świetle Analiz Petrograficznych. In Proceedings of the XIII Konferencja Stratygrafia Plejstocenu Polski Plejstocen Południowej Warmii i Zachodnich Mazur na tle Struktur Podłoża, Maróz, Poland, 4-8 September 2006; Morawski, W., Ed.; Państwowy Instytut Geologiczny: Warszawa, Poland, 2006 ; pp. 50-52.

40. Górska-Zabielska, M.; Wachecka-Kotkowska, L. Petrografia Żwirów i Eratyki Przewodnie w Osadach Wodnolodowcowych Jako Przesłanki Wnioskowania Na Temat Źródeł i Kierunków Transportu Materiału w Obszarze Między Piotrkowem Trybunalskim, Radomskiem a Przedborzem (Środkowa Polska) (in Polish with English Abstract). Acta Geogr. Lodz. 2015, 103, 57-77.

41. Lipka, E. New Findings of the Oslo Region Erratics in Glaciofluvial Deposits of NW Poland. Landf. Anal. 2019, 38, 3-11. [CrossRef]

42. Strzelecki, P.J. The Provenance of Erratic Pebbles from a till in the Vicinity of the City of Radom, Central Poland. Geol. Geophys. Environ. 2019, 45, 21-29. [CrossRef]

43. Nitychoruk, J.; Zbucki, Ł.; Rychel, J.; Woronko, B.; Marks, L. Extent and Dynamics of the Saalian Ice-Sheet Margin in Neple, Eastern Poland. Bull. Geol. Soc. Finl. 2018, 90, 85-190. [CrossRef]

44. Górska, M. Advantages and Disadvantages of Petrographic Analyses of Glacial Sediments. Geol. Q. 1999, 43, 241-250.

45. Stokes, C.R.; Clark, C.D. Geomorphological Criteria for Identyfying Pleistocene Ice Streams. Ann. Glaciol. 1999, $28,67-75$. [CrossRef]

46. Stokes, C.R.; Clark, C.D. Palaeo-Ice Streams. Quatern. Sci. Rev. 2001, 20, 1437-1457. [CrossRef]

47. Kjær, K.H.; Houmark-Nielsen, M.; Richardt, N. Ice-Flow Patterns and Dispersal of Erratics at the Southerwestern Margin of the Last Scandinavian Ice Sheet: Signature of Palaeo-Ice Streams. Boreas 2003, 32, 130-148. [CrossRef]

48. Jørgensen, F.; Piotrowski, J.A. Signature of the Baltic Ice Stream on Funen Island, Denmark during the Weichselian Glaciation. Boreas 2003, 32, 242-255. [CrossRef]

49. Górska-Zabielska, M. Wstępne Wyniki Analizy Petrograficznej Osadów w Żwirowni Łubienica-Superunki (in Polish with English Abstract). Landf. Anal. 2017, 33, 3-9.

50. Czubla, P.; Forysiak, J.; Petera-Zganiacz, J. Lithological and Petrographic Features of Tills in the Koźmin Region and Their Value for Stratigraphical Interpretation of Glacial Lake Koźmin Deposits, Central Poland. Geologija 2010, 52, 1-8. [CrossRef]

51. Czubla, P.; Terpiłowski, S.; Orłowska, A.; Zieliński, T.; Pidek, I.A. Petrographic Features of Tills as a Tool in Solving Stratigraphical and Palaeogeographical Problems-A Case Study from Central-Eastern Poland. Quat. Int. 2019, 501, 45-58. [CrossRef]

52. Górska-Zabielska, M.; Wachecka-Kotkowska, L. Petrographical Analysis of Warthian Fluvioglacial Gravels as a Tool to Trace the Source Area-A Case Study from Central Poland. Geologos 2014, 20, 183-199. [CrossRef]

53. Nunberg, J. Próba Zastosowania Metod Statystycznych Do Badania Zespołu Głazów Fennoskandyjskich Występujących w Utworach Glacjalnych Północno-Wschodniej Polski (in Polish with English Summary). Stud. Geol. Pol. 1971, 37, 1-107.

54. Haldorsen, S. The Enrichment of Quartz in Tills. In Till and Related Deposits, Proceedings of the INQUA-Symposia on the Genesis and Lithology of Quaternary Deposits, Argentina, 10-20 September 1982; Evenson, E.B., Schlüchter, C., Rabassa, J., Eds.; Balkema: Rotterdam, The Netherlands, 1982; pp. 141-150.

55. Górska, M. Wybrane Właściwości Petrograficzne Vistuliańskich Moren Dennych Środkowej i Zachodniej Wielkopolski Oraz Ich Znaczenia Dla Oceny Dynamiki Ostatniego Ladolodu (in Polish with English Summary); Prace Komisji Geograficzno-Geologicznej Poznańskiego Towarzystwa Przyjaciół Nauk: Poznań, Poland, 2000; pp. 1-145.

56. Rutkowski, J. Wprowadzenie w Badania Petrograficzne Żwirów. In Analizy sedymentologiczne osadów glacigenicznych; Harasimiuk, M., Terpiłowski, S., Eds.; Wydawnictwo UMCS: Lublin, Poland, 2003; pp. 13-21.

57. Woźniak, P. Przydatność Analizy Litologicznej Glin Morenowych w Badaniach Geomorfologicznych Stref Marginalnych Ostatniego Zlodowacenia (in Polish with English Abstract). Przegląd Geologiczny 2004, 52, 336-339.

58. Woźniak, P.P.; Czubla, P.; Wysiecka, G.; Drapella, M. Petrographic Composition and Directional Properties of Tills on the NW Surroundings of the Gdańsk Bay, Northern Po-Land. Geologija 2009, 51, 59-67. [CrossRef]

59. Górska, M. Analiza Petrograficzna Narzutniaków Skandynawskich (in Polish). In Analizy Sedymentologiczne Osadów Glacigenicznych; Harasimiuk, M., Terpiłowski, S., Eds.; Wydawnictwo UMCS: Lublin, Poland, 2003; pp. $23-31$.

60. Górska, M. Narzutniaki Przewodnie z Sobolewa (Sandr Suwalsko-Augustowski) (in Polish with English Summary). Prace Komisji Paleogeografii Czwartorzędu PAU 2006, 3, 209-212.

61. Lipka, E. Zróżnicowanie Cech Petrograficznych Osadów Polodowcowych Na Wysoczyźnie Lubuskiej (in Polish with English Abstract). Ph.D. Thesis, Instytutu Geoekologii i Geoinformacji UAM, Poznań, Poland, 2012.

62. Lüttig, G. Erratic Boulder Statistics as a Stratigraphic Aid-Examples from Schleswig-Holstein. Newsl. Stratigr. 1991, 25, 61-74. [CrossRef]

63. Lüttig, G. Geschiebestatistische Anmerkungen Zur Quartärstratigraphie Des Nordischen Vereisungsgebietes. EEG Quaternary Sci. J. 1999, 49, 144-163. [CrossRef]

64. Jurgaitis, A. Genetic Types and Lithology of Gravel of Lithuanian SSR. Ministry of Geology of the USSR; The Vilniius Geological Institute; Transactions; Ministry of Geology of the USSR: Vilnus, Lithuania, 1969.

65. Jurgaitis, A. Litogenez Fluwioglacjalnych Otłożenii Obłastii Poslednego Materikowogo Oledenija (in Russian); Litowskij NaucznoIssledowatelskij Geologorazwiedocznyj Institut: Moscow, Russia, 1984. 
66. Danilans, I.J. Czetwierticznyje Otłożenija Latwii. Ministerstwo Geołogii SSSR; Wsesojuznyj Nauczno-Issledowatelskij Institut Morskoj Geołogii i Geografii: Riga, Latvia, 1973.

67. Mikalajskas, A.P. Fluwioglacjalnyje Rawniny Litwy (in Russian); Mokslac: Vilnius, Lithuania, 1985.

68. Saarnisto, M. An Outline of Glacial Indicator Tracing. In Glacial Indicator Tracing; Kujansuu, R., Saarnisto, M., Eds.; Balkema: Rotterdam, The Netherlands, 1990; pp. 1-13.

69. Marks, L. Quaternary Glaciations in Poland. In Quaternary Glaciations-Extent and Chronology, a Closer Look; Ehlers, J., Gibbard, P.L., Hughes, P.H., Eds.; Developments in Quaternary Science; Elsevier: Amsterdam, The Netherlands, 2011; Volume 15, pp. $299-303$.

70. Wachecka-Kotkowska, L. Rozwój Rzeźby Obszaru Między Piotrkowem Trybunalskim, Radomskiem a Przedborzem w Czwartorzędzie (in Polish with English Summary); Wydawnictwo Uniwersytetu Łódzkiego: Łódź, Poland, 2015.

71. Czubla, P.; Sokołowski, R.J. Did the Baltic Ice Stream Exist during the Late Saalian? New Data from the Northern Wielkopolska and Eastern Pomerania Regions, Poland. In Proceedings of the International Field Symposium of the INQUA PeriBaltic Working Group (Greifswald 2019), Postdam, Germany, 19 January 2019. [CrossRef]

72. Sokołowski, R.J.; Czubla, P. Sequence of Pleistocene Deposits in the Wapienno Quarry, North-Central Poland. In Quaternary Geology of North-Central Poland: From the Baltic Coast to the LGM Limit in INQUA Peribaltic Working Group; Sokołowski, R.J., Moskalewicz, D., Eds.; University of Gdańsk: Gdańsk, Poland, 2016; pp. 69-84.

73. Giriat, D.; Smolska, E.; Woźniak, B. Cechy Sedymentologiczne Osadów Wodnolodowcowych w Żwirowni Łubienica-Superunki (Południowo-Wschodnia Część Wysoczyzny Ciechanowskiej) (in Polish with English Abstract). Landf. Anal. 2017, 33, 25-36. [CrossRef]

74. Smolska, E.; Giriat, D.; Woźniak, B.; Zawadzka-Pawlewska, U. Wybrane Cechy Sedymentologiczne Osadów i Ich Znaczenie w Rozdzieleniu Poziomów Wodnolodowcowych w Żwirowni Łubienica-Superunki (SE Wysoczyzna Ciechanowska) (in Polish with English Abstract). In Geneza, Litologia i Stratygrafia Utworów Czwartorzędowych; Kostrzewski, A., Stach, A., Majewski, M., Eds.; Instytut Geoekologii i Geoinformacji Uniwersytet im. A. Mickiewicza: Poznań, Poland, 2018; Volume VII, pp. $171-175$.

75. Dąbski, M.; Zawadzka-Pawlewska, U.; Greń, K. Struktury Peryglacjalne Na Stanowisku Łubienica-Superunki (Wysoczyzna Ciechanowska)-Wstępne Wyniki Badań (in Polish with English Abstract). Landf. Anal. 2017, 33, 7-24.

76. Frankiewicz, A. Materiały Robocze Do Szczegótowej Mapy Geologicznej Polski w Skali 1:50000, Arkusz Serock (in Polish); Państwowy Instytut Geologiczny_Państwow Instytut Badawczy: Warszawa, Poland, 2017.

77. Zabielski, R. Badania Litologiczno-Petrograficzne Osadów Plejstoceńskich (in Polish). In Szczegótowa Mapa Geologiczna Polski w Skali 1:50,000, Ark. Wyszków (in Polish); Państwowy Instytut Geologiczny—Państwow Instytut Badawczy: Warszawa, Poland, 2006.

78. Kucharska, M.; Pochocka-Szwarc, K. Objaśnienia Do Szczegółowej Mapy Geoligicznej Polski, Ark. Wyszków (451) (in Polish); Archiwum Państwowego Instytutu Geologicznego-Państwowego Instytutu Badawczego: Warszawa, Poland, 2012.

79. Nowak, J. Objaśnienia Do Szczegółowej Mapy Geologicznej Polski, Arkusz Serock (N34-127A) (in Polish); Wydawnictwa Geologiczne: Warsaw, Poland, 1969.

80. Nowak, J. O Występowaniu Złóż Iłów Pstrych w Okolicy Bud Obrębskich. Przegląd Geol. 1958, 6, 493-494.

81. Miall, A.D. The Geology of Fluvial Deposits. Sedimentary Facies, Basin Analysis, and Petroleum Geology; Springer: Berlin/Heidelberg, Germany; New York, NY, USA, 1996.

82. Zieliński, T. Kod Litofacjalny i Litogenetyczny-Konstrukcja i Zastosowanie. (Lithofacies and Genetic Codes: Construction and Appli-Cation). In Badania Osadów Czwartorzędowych (Researches of Quaternary Sediments); Mycielska-Dowgiałło, E., Rutkowski, J., Eds.; Warsaw University Press: Warsaw, Poland, 1995; pp. 220-235.

83. Zieliński, T.; Pisarska-Jamroży, M. Jakie Cechy Litologiczne Osadów Warto Kodować, a Jakie Nie? Przegląd Geol. 2012, 60, 387-397.

84. Meyer, K.-D. Zur Methodik Und Über Den Wert von Geschiebezählungen. Geschiebesammler 1985, 19, 75-83.

85. Trembaczowski, J. Przyczynki Do Metodyki Badań Granulometryczno-Petrograficznych Utworów Morenowych (in Polish with English Summary). Ann. Univ. M Curie-Skłodowska Sec. B 1961, 16, 63-95.

86. Trembaczowski, J. Granulometryczno-Petrograficzna Charakterystyka Glin Zwałowych Wysoczyzny Konińskiej (in Polish with English Summary). Inst. Geoogicznego 1967, 48, 147-162.

87. Böse, M. Die Geomorphologische Entwicklung im Westlichen Berlin Nach Neueren Stratigraphischen; Berliner Geographische Abhandlungen: Berlin, Germany, 1979; Volume 28.

88. Böse, M. Methodisch-Stratigraphische Studien Und Paläomorphologische Untersuchungen Zum Pleistozän Südlich Der Ostsee; Berliner Geographische Abhandlungen: Berlin, Germany, 1989.

89. Rutkowski, J. Badania Petrograficzne Żwirów (in Polish with English Summary). In Badania Osadów Czwartorzędowych. Wybrane Metody i Interpretacja Wyników; Mycielska-Dowgiałło, E., Rutkowski, J., Eds.; Wydział Geografii i Studiów Regionalnych Uniwersytetu Warszawskiego: Warsaw, Poland, 1995; pp. 133-150.

90. Rutkowski, J. Badania Uziarnienia Osadów Bardzo Gruboziarnistych (in Polish with English Summary). In Badania osadów czwartorzędowych. Wybrane Metody i Interpretacja Wyników; Mycielska-Dowgiałło, E., Rutkowski, J., Eds.; Wydział Geografii i Studiów Regionalnych Uniwersytetu Warszawskiego: Warsaw, Poland, 1995; pp. 106-111.

91. Cohen, K.M.; Gibbard, P.L. Chronostratigraphical Correlation Table for the Last 2.7 Million Years, Version 2019 QI-500. Quat. Int. 2019, 500, 20-31. [CrossRef]

92. Marks, L.; Karabanov, A.; Nitychoruk, J.; Bahdasarau, M.; Krzywicki, T.; Majecka, A.; Pochocka-Szwarc, K.; Rychel, J.; Woronko, B.; Zbucki, Ł.; et al. Revised Limit of the Saalian Ice Sheet in Central Europe. Quat. Int. 2018, 478, 47-59. [CrossRef] 
93. Balzam, B. Złoże Pospótki w kat. C1 w Dzierżeninie (in Polish); Archiwum Przedsiębiorstwa Geologicznego Budownictwa: Warszawa, Poland, 1958.

94. Marcinkowski, B. Badania Litologiczno-Petrograficzne Dla Szczegółowej Mapy Geologicznej Polski w Skali 1:50000, Arkusz Serock (in Polish); Państwowy Instytut Geologiczny_Państwowy Instytut Badawczy: Warszawa, Poland, 2017.

95. Górska, M. Narzutniaki Skandynawskie-Metodyka Badań i Interpretacja. Analiza Eratyków Ze Stanowiska w Koczerach Koło Dro-Hiczyna (in Polish). In Warsztaty terenowe Osady, Struktury Deformacyjne i Formy Warciańskiej Strefy Glacjomarginalnej na Nizinie Podlaskiej; Uniwersytet Marii Curie-Skłodowskiej: Lublin, Poland, 2000; pp. 25-29.

96. Górska-Zabielska, M.; Smolska, E.; Wachecka-Kotkowska, L. Analiza Petrograficzna i Obszary Alimentacyjne Narzutniaków w Żwirowni Łubienica-Superunki. [Petrographic Analysis and Source Areas of Erratics in Łubienica-Superunki Gravel Pit]. Przeglad Geol. 2021, 69, 4-54. [CrossRef]

97. Punkari, M. Subglacial Processes of the Scandinavian Ice Sheet in Fennoscandia Inferred from Flow-Parallel Features and Lithostratigraphy. Sediment. Geol. 1997, 111, 263-283. [CrossRef]

98. Ehlers, J. Reconstructing the Dynamics of the North-West European Pleistocene Ice-Sheet. Quat. Sci. Rev. 1990, 9, 71-83. [CrossRef]

99. Lisiecki, L.E.; Raymo, M.E. A Pliocene-Pleistocene Stack of 57 Globally Distributed Benthic $\delta 18$ O Records: Pliocene-Pleistocene Benthic Stack. Paleoceanography 2005, 20, 1-17. [CrossRef]

100. Railsback, L.B.; Gibbard, P.L.; Head, M.J.; Voarintsoa, N.R.G.; Toucanne, S. An Optimized Scheme of Lettered Marine Isotope Substages for the Last 1.0 Million Years, and the Climatostratigraphic Nature of Isotope Stages and Substages. Quat. Sci. Rev. 2015, 111, 94-106. [CrossRef] 